\title{
1 The fate of the Deep Western Boundary Current in the South Atlantic
} 24 in the South Atlantic is along the western boundary (similar to the North Atlantic). In 25 addition to the western boundary pathway, tracers show an eastward spreading of NADW
${ }^{1}$ Cooperative Institute for Marine and Atmospheric Studies, University of Miami

${ }^{2}$ NOAA/Atlantic Oceanographic and Meteorological Laboratory

${ }^{3}$ Rosenstiel School of Marine and Atmospheric Sciences, University of Miami

${ }^{4}$ ARC Centre of Excellence for Climate System Science \& Climate Change Research Centre, UNSW, Sydney, New South Wales, Australia

${ }^{5}$ Now at Grantham Institute \& Department of Physics, Imperial College London, London, United Kingdom

\section{Abstract}

The pathways of recently ventilated North Atlantic Deep Water (NADW) are part of the lower limb of the Atlantic Meridional Overturning Circulation (AMOC). In the South Atlantic these pathways have been the subject of discussion for years, mostly due to the lack of observations. Knowledge of the pathways of the AMOC in the South Atlantic is a first order prerequisite for understanding the fluxes of climatically important properties. In this paper, historical and new observations, including hydrographic and oxygen sections, Argo data, and chlorofluorocarbons (CFCs), are examined together with two different analyses of the Ocean general circulation model For the Earth Simulator (OFES) to trace the pathway of the recently ventilated NADW through the South Atlantic. CLIVAR-era CFCs, oxygen and salinity clearly show that the strongest NADW pathway 
26 between $\sim 17-25^{\circ} \mathrm{S}$. Analyzed together with the results of earlier studies, the observations

27 and model output presented here indicate that after crossing the equator, the Deep

28 Western Boundary Current (DWBC) transports water with the characteristics of NADW

29 and a total volume transport of approximately $14 \mathrm{~Sv}\left(1 \mathrm{~Sv}=10^{6} \mathrm{~m}^{3} \mathrm{~s}^{-1}\right)$. It crosses $5^{\circ} \mathrm{S}$ as

30 a narrow western boundary current and becomes dominated by eddies further south.

31 When this very energetic eddying flow reaches the Vitória-Trindade Ridge $\left(\sim 20^{\circ} \mathrm{S}\right)$, the

32 flow follows two different pathways. The main portion of the NADW flow continues

33 along the continental shelf of South America in the form of a strong reformed DWBC,

34 while a smaller portion, about $22 \%$ of the initial transport, flows towards the interior of

35 the basin.

36

\section{1. Introduction}

38 The role of the southward flowing Deep Western Boundary Current (DWBC) as a

39 primary pathway for the cold, lower limb of the Atlantic Meridional Overturning

40 Circulation (AMOC) has been well documented in the North Atlantic Ocean (e.g.

41 Molinari et al., 1998; Schott et al., 2004; Johns et al., 2008; Meinen et al., 2012) ${ }^{1}$.

42 However the pathways and variability of the DWBC as the lower limb of the overturning

\footnotetext{
${ }^{1}$ Note: One exception to this is near and south of the Grand Banks of Newfoundland, where Lagrangian floats suggest that the DWBC flow breaks up and interacts significantly with the interior (e.g. Bower et al., 2009).
} 
43 circulation in the South Atlantic Ocean are less well established. Much of what is known

44 about the deep flows in the South Atlantic has been inferred from the merging of

45 hydrographic sections in the region. They are used to trace the North Atlantic Deep

46 Water (NADW), the main water mass carried by the DWBC. For example, Reid's (1989)

47 maps of geopotential anomaly of the $3000 \mathrm{db}$ surface with respect to the $3500 \mathrm{db}$ surface

48 indicate that part of the NADW from the DWBC flows to the interior near $25^{\circ} \mathrm{S}$

49 producing eastward tongues of high salinity and oxygen extending close to the Mid-

50 Atlantic Ridge. Reid's analysis of salinity, oxygen, phosphate, and silica also suggests

51 eastward flow towards the interior.

52 There are few direct observations of the DWBC in the South Atlantic. A two year-long

53 velocity and temperature time series from a moored array, shipboard observations, and

54 model simulations previously suggested that the southward flowing DWBC breaks up

55 into eddies before reaching $8^{\circ} \mathrm{S}$ (Dengler et al., 2004). They reported that between $8^{\circ} \mathrm{S}$

56 and $16^{\circ} \mathrm{S}$, the transport of NADW into the South Atlantic Ocean is accomplished by

57 southeastward migrating eddies, rather than by a continuous flow. Direct current meter

58 observations by Schott et al. (2005) supported the idea that a mean DWBC exists at $5^{\circ} \mathrm{S}$

59 and dissolves into a sequence of deep eddies between $5^{\circ} \mathrm{S}$ and $11^{\circ} \mathrm{S}$. Hogg and Owens

60 (1999) analyzed observations collected from Lagrangian floats launched as part of the 
61 Deep Basin Experiment. They concluded that the line of sea mounts that extends

62 eastward from the South American coast just south of $20^{\circ} \mathrm{S}$ rising to depths of $2000 \mathrm{~m}$ or

63 less at places, (known as the Vitória-Trindade Ridge), interrupts the southward-flowing

64 DWBC and is the location for significant eddy exchange into the interior. Their float

65 trajectories provided little indication of a continuation of the DWBC flowing southward

66 beyond the Vitória-Trindade Ridge, although a single float trajectory did return to the

67 western boundary south of $20^{\circ} \mathrm{S}$.

68 Further south, direct current measurements (Muller et al., 1998) and geostrophic current

69 estimates (Zangenberg and Siedler, 1998) have hinted at the existence of a DWBC along

70 the continental slope between $20^{\circ} \mathrm{S}$ and $28^{\circ} \mathrm{S}$, with a southward transport that ranges

71 between 2 and $10 \mathrm{~Sv}\left(1 \mathrm{~Sv}=10^{6} \mathrm{~m}^{3} \mathrm{~s}^{-1}\right)$. This might suggest the presence of at least a

72 portion of the DWBC along the western boundary south of the Vitória-Trindade Ridge. A

73 more recent study (Meinen et al., 2012) used data from a line of four pressure equipped

74 inverted echo sounders (PIES) as well as hydrographic and dissolved oxygen $\left(\mathrm{O}_{2}\right)$

75 measurements to study the DWBC along $34.5^{\circ} \mathrm{S}$ on the South American continental

76 shelf/slope. These data have confirmed the presence of a DWBC with water mass

77 characteristics of NADW (elevated oxygen and salinity) at $34.5^{\circ} \mathrm{S}$.

78 On the other side of the Atlantic basin at $30^{\circ} \mathrm{S}$, hydrographic sections have also been used 
79 to show southward flow of water with characteristics of NADW along the eastern

80 boundary and a mean transport of $3 \mathrm{~Sv}$ (Arhan et al., 2003). These observations are

81 consistent with a portion of the NADW perhaps having followed an interior pathway over

82 to the eastern boundary. Because of the paucity of observations to date, the details of this

83 interior pathway are still quite uncertain.

84 Enhancements to the suite of measurements made during hydrographic cruises over the

85 past decades allow for these hydrographic data to yield more information on ocean

86 pathways than were previously possible. For example, hydrographic sections of salinity

87 and dissolved oxygen from the WOCE Atlas Volume 3, Atlantic Ocean (http://www-

88 pord.ucsd.edu/whp_atlas/atlantic/sections.htm) show clear evidence of water with the

89 NADW characteristics (i.e., low temperature, $\mathrm{T} \sim 3^{\circ} \mathrm{C}$, and high salinity, $\mathrm{S}>34.8 \mathrm{psu}$,

90 water with high levels of dissolved oxygen, $\mathrm{O}_{2}>240 \mu \mathrm{mol} \mathrm{kg} \mathrm{kg}^{-1}$ ) along the western

91 boundary at $11^{\circ} \mathrm{S}, 19^{\circ} \mathrm{S}$, and $30^{\circ} \mathrm{S}$ (Koltermann et al., 2011). The NADW can also be

92 traced by looking for waters with high concentrations of chlorofluorocarbons (CFCs)

93 (Fine et al., 2002); recently ventilated NADW carries an elevated CFC concentration

94 because it has been more recently in contact with the atmosphere than the older waters at

95 the same depths that were last in contact with the atmosphere before the measurable CFC

96 transient ( 1960s). The high CFC NADWs flow equatorward from the high latitude 
97 North Atlantic in the DWBC (e.g., Fine and Molinari, 1988; Smethie et al., 2000) and

98 along the equator (Weiss et al., 1985). Wanninkhof et al. (2010) analyzed repeat

99 observations from the meridional Atlantic section A16 along $\sim 25^{\circ} \mathrm{W}$ from Iceland to

$10056^{\circ} \mathrm{S}$. The composite quasi-meridional sections from the 2003 and 2005 A16 cruises for

101 salinity, apparent oxygen utilization, total dissolved inorganic carbon, nitrate, and silicate

102 show that water masses with NADW properties are present at $20^{\circ} \mathrm{S}$ in the center of the

$103 \operatorname{basin}\left(\sim 25^{\circ} \mathrm{W}\right)$.

104 Numerical models have also been used to improve our understanding of the spreading of

105 the NADW into the South Atlantic. Speich et al. (2007) computed trajectories of the

106 particles that represent the southward flow of NADW at $44^{\circ} \mathrm{N}$ in the North Atlantic (i.e.,

107 characterized by a potential density anomaly greater than $27.7 \mathrm{~kg} \mathrm{~m}^{-3}$ ). Trajectories were

108 computed in a coarse-resolution ocean general circulation model $\left(2^{\circ}\right.$ uniform zonal

109 resolution, and meridional resolution that varies from $0.5^{\circ}$ at the equator to $2^{\circ} \cos (\phi)$

110 poleward of the tropics). This coarse resolution Lagrangian simulation shows NADW

111 flowing southward along the coast of South America in the DWBC to approximately

$11245^{\circ} \mathrm{S}$, after which it flows into the interior towards the east. Although analysis of a global

113 eddy-permitting (nominal horizontal resolution of $0.25^{\circ}$ ) Parallel Ocean Climate Model

114 (POCM) by Matano and Beier (2003) similarly demonstrated the main pathway for the 
115 DWBC is along the coast of South America, there were also some indications of another

116 pathway flowing into the interior along approximately $27^{\circ} \mathrm{S}$.

117 More recently, van Sebille et al. (2012) utilized the output from the global high-

118 resolution $\left(0.1^{\circ}\right.$ horizontal resolution) Ocean general circulation model For the Earth

119 Simulator (OFES) model to study the NADW pathways in the South Atlantic. They

120 found $3.6 \mathrm{~Sv}$ of NADW crossing eastward at about $25^{\circ} \mathrm{S}$ underneath the trajectory

121 followed by the Agulhas rings that detach from the Agulhas Retroflection and then

122 slowly drift northwestward along the so-called Agulhas ring corridor. They analyzed the

123 velocity and density fields of the last 27-years of output from a 57-year (1950-2006) run

124 of the OFES model and found that the decay of the Agulhas rings, and their forward tilt

125 with depth, results in a southward velocity of 1 to $2 \mathrm{~cm} / \mathrm{s}$ across isolines of planetary

126 vorticity in the deep waters. The associated stream function pattern yields a deep

127 circulation transporting about $4 \mathrm{~Sv}$ of NADW from the DWBC eastward at $25^{\circ} \mathrm{S}$ to the

128 southern tip of Africa. The pathway of the DWBC and how it reforms along the western

129 boundary south of $25^{\circ} \mathrm{S}$ were not the objective of the analysis conducted by van Sebille et

130 al. (2012), and will be analyzed in detail in what follows using the OFES model and

131 available observations.

132 Previous modeling and observational work has shown that important water mass 
133 transformations occur in the South Atlantic (e.g., Garzoli and Matano, 2011, and

134 references therein). For example, transformations occur in the very energetic regions near

135 the boundaries such as the Brazil-Malvinas Confluence and the Cape Basin (Provost et al.,

136 1999; Lumpkin and Speer, 2007; Jullion et al., 2010; Garzoli and Matano, 2011; Rimaud

137 et al., 2012). These water mass transformation regions will both influence and be

138 influenced by the pathways of the DWBC as it flows through the South Atlantic, and the

139 transformations will have important impacts on the AMOC. The stability of the AMOC

140 has been shown to be directly related to meridional salt fluxes between the South Atlantic

141 and other ocean basins (e.g., Drijfhout et al., 2011; Bryden et al., 2011; Garzoli et al.,

142 2013). Developing a detailed knowledge and understanding of the pathways of the lower

143 limb of the AMOC will therefore be crucial for quantifying the fluxes of heat, fresh water,

144 and $\mathrm{CO}_{2}$ through the South Atlantic and for assessing the stability of the AMOC.

145 The objective of this paper is to utilize existing and recent hydrographic and tracer data

146 sets, a new gridded subsurface Argo data product (Schmid, 2014), and Eulerian and

147 Lagrangian analyses from the high-resolution OFES model, to extend the previous work

148 conducted by van Sebille et al. (2012) and to learn more about the western boundary and

149 interior pathways of the NADW in the South Atlantic. Furthermore the transports

150 associated with these pathways will be quantified and will demonstrate the strength of the 
151 flow along the western boundary pathway, which has historically been underestimated.

152

\section{2. Observational Evidence}

\section{$154 \quad 2.1$ Pathways based on hydrographic and CFC tracers}

155 The recently ventilated NADW carried by the lower limb of the AMOC is characterized

156 by low temperature $\left(\sim 3^{\circ} \mathrm{C}\right)$, high salinity $(\mathrm{S}>34.8 \mathrm{psu})$, and high levels of dissolved

157 oxygen $\left.\left(\mathrm{O}_{2}>240 \mu \mathrm{mol} \mathrm{kg}\right)^{-1}\right)$. This NADW flows southward at neutral density levels

158 between 27.9 and $28.1 \mathrm{~kg} \mathrm{~m}^{-3}$ in the South Atlantic near $35^{\circ} \mathrm{S}$ (Schmitz and McCartney,

159 1992; Meinen et al., 2012; Preu et al., 2013). Inspection of the CTD sections collected

160 during the WOCE experiment at $11^{\circ} \mathrm{S}, 19^{\circ} \mathrm{S}$ and $30^{\circ} \mathrm{S}$ (Koltermann et al., 2011) show

161 that water masses with these characteristics in the South Atlantic are concentrated in the

162 western basin between 1500 and $3000 \mathrm{~m}$ depth. At $11^{\circ} \mathrm{S}$ these water are observed west of

$16320^{\circ} \mathrm{W}$, and at $19^{\circ} \mathrm{S}$ and $30^{\circ} \mathrm{S}$ the recently ventilated NADW is found as far offshore as $1645^{\circ} \mathrm{W}$.

165

166 As mentioned in the introduction recently ventilated NADW can be tracked using other

167 CFCs. Using the WOCE data era (1992-1997), maps of chlorofluorocarbon-11 (CFC-11)

168 concentrations are generated via the data-interpolating variational analysis (DIVA) 
169 gridding technique (Troupin et al. 2012) applied to the South Atlantic (Figure 1) on

170 neutral density level $27.9 \mathrm{~kg} \mathrm{~m}^{-3}$, the level of the upper NADW between 1700 and 2000

$171 \mathrm{~m}$. High concentrations $\left(>0.03 \mathrm{pmol} \mathrm{kg}^{-1}\right)$ of CFC-11 are observed along the western

172 boundary in the North Atlantic, along the equator, and extending into the South Atlantic

173 along the western boundary north of $5^{\circ} \mathrm{N}$ (Figure 1). On the WOCE era map,

174 concentrations above $0.05 \mathrm{pmol} \mathrm{kg}^{-1}$ are found extending into the South Atlantic along

175 the western boundary only to $\sim 15^{\circ} \mathrm{S}$. However, there is evidence of elevated

176 concentrations $\left(>0.04 \mathrm{pmol} \mathrm{kg}^{-1}\right)$ of recently ventilated NADW in the interior near $23^{\circ} \mathrm{S}$,

$17735^{\circ} \mathrm{W}$. Ventilated NADW is defined here as those waters of NADW origin that carry

178 above blank level CFC-11 (i.e. CFC-11 values $>0.005 \mathrm{pmol} \mathrm{kg}^{-1}$ ). CFCs are a transient

179 tracer, and they increased in NADW well after the mid-1990s (e.g., Kieke et al., 2007).

180 As a consequence, the southward and eastward spreading of ventilated NADW is

181 probably limited in the WOCE era data, as they had not yet had time to spread.

182

183 To investigate this point further, CLIVAR transect data (repeats of WOCE-era transects

184 obtained during the first two decades of the 2000s) have been analyzed in this study. CFC

185 data in the South Atlantic south of $10^{\circ} \mathrm{S}$ and north of $40^{\circ} \mathrm{S}$ were collected along the

186 following CLIVAR sections: $\mathrm{A} 13 \sim 5^{\circ}-10^{\circ} \mathrm{E}$ in 2010 , $\mathrm{A} 1520^{\circ} \mathrm{W}$ in $2000, \mathrm{~A} 16 \mathrm{~S} \sim 25^{\circ} \mathrm{W}$ in

1872005 and 2013-2014, and A10 30 ${ }^{\circ} \mathrm{S}$ in 2003 and 2011 (see brown lines in Figure 1). 
188 Although other sections were occupied in the South Atlantic, they did not collect CFC

189 measurements. Thus, there are not enough CLIVAR data with which to make a map of

190 CFC concentrations, similar to what was done for WOCE data of the 1990s (Figure 1).

191 Instead, data from $\mathrm{A} 10\left(\sim 30^{\circ} \mathrm{S}\right)$, A16S $\left(\sim 25^{\circ} \mathrm{W}\right)$ and $\mathrm{A} 13\left(\sim 5^{\circ}-10^{\circ} \mathrm{E}\right)$ are presented as

192 individual cross-sections of high CFCs, oxygen and salinity, which are used to show for

193 the first time the eastward spreading of NADW into the central South Atlantic Ocean

194 (Figure 2).

195

196 Between $\sim 17^{\circ}-25^{\circ} \mathrm{S}$ the NADW has reached as far east as $25^{\circ} \mathrm{W}$ during the 2005 (not 197 shown) and 2013-2014 (Figure 2a-c) occupations and there is a suggestion of elevated 198 CFCs at $5^{\circ}-10^{\circ} \mathrm{E}$ south of $28^{\circ} \mathrm{S}$ during the 2010 occupation (Figure $2 \mathrm{~d}$ ). This can be more 199 clearly seen along $30^{\circ} \mathrm{S}$ (Figure 2e), as a large area with elevated CFCs $>0.01 \mathrm{pmol} \mathrm{kg}^{-1}$ 200 is observed to extend east of Walvis Ridge between $5^{\circ}$ and $15^{\circ} \mathrm{E}$. Note that the high tracer 201 cores (CFC-11, salinity and oxygen) are not completely overlapping in space. If the high 202 CFC-11 core in Figure 2a is taken as $0.04 \mathrm{pmol} \mathrm{kg}^{-1}$, then indeed it does occupy the same 203 depths as the oxygen and salt cores of Figures $2 b$ and $2 c$. Furthermore, the high salinity 204 core reaches upward to almost $1500 \mathrm{~m}$ as does the CFC-11, but not oxygen. In addition, 205 highest concentrations of CFC-11 are observed at shallower depths $1500-2400 \mathrm{~m}$ in 206 Figure 2a, as compared with Figure 2e where the highest CFC-11 is observed at 2000$2072400 \mathrm{~m}$. The upper part of the high CFC-11 core in Figure $2 \mathrm{a}$ at approximately $22^{\circ} \mathrm{S}$, $20825^{\circ} \mathrm{W}$ is of Labrador Sea origin. A probable explanation for the difference in signatures at 
209 the two latitudes is that at $30^{\circ} \mathrm{S}$ near the western boundary the shallower Labrador Sea

210 Water has been largely replaced with waters of southern origin and lower CFC-11, for

211 example, Upper Circumpolar Deep Water.

212

213 Figure 2e shows the highest subsurface CFC concentrations $\left(>0.2 \mathrm{pmol} \mathrm{kg}^{-1}\right)$ in NADW

214 along the western boundary at $30^{\circ} \mathrm{S}$. High CFCs spreading southward in the WBC is

215 consistent with recent dissolved oxygen measurements collected during hydrographic

216 cruises along the western boundary near $35^{\circ} \mathrm{S}$ (Schmitz and McCartney, 1992; Meinen et

217 al., 2012; Preu et al., 2013). In time, as the CFC transient penetrates the South Atlantic,

218 on future occupations of the $\sim 25^{\circ} \mathrm{W}, \sim 5^{\circ}-10^{\circ} \mathrm{E}$, and $30^{\circ} \mathrm{S}$ sections, it may be possible to

219 observe interior eastward flowing NADW that has turned southward near the eastern

220 boundary east of Walvis Ridge. To summarize, the CLIVAR-era CFCs, oxygen and

221 salinity demonstrate that the strongest NADW signal in the South Atlantic (similar to the

222 North Atlantic) is along the western boundary and that there is eastward spreading of

223 NADW between $\sim 17^{\circ}-25^{\circ} \mathrm{S}$, and NADW is observed east of the Walvis Ridge at $30^{\circ} \mathrm{S}$.

224

$225 \quad 2.2$ Argo data

226 The Argo array is a global set of more than 3,000 free-drifting floats that sample the

227 upper ocean to a maximum pressure level of 2000 dbar, which is within the upper layer

228 of the NADW. Schmid (2014) developed a procedure to obtain three-dimensional fields 
229 of absolute geostrophic velocities from Argo and altimeter data. Results were published

230 for the period ending in June 2012. In an expansion of Schmid (2014), 66,264 profiles of

231 temperature and salinity collected in the South Atlantic in the years 2000 to 2013 , were

232 used to generate an updated product for this study. The 3-D velocity field extends from

233 the surface to $2000 \mathrm{dbar}$ with a vertical resolution of $10 \mathrm{dbar}$. Velocity fields are derived

234 by first combining in situ dynamic height profiles from floats with the sea surface height

235 from AVISO (CLS, 1996) to generate synthetic dynamic height profiles with better

236 spatial and temporal coverage than could be achieved using only the in situ observations.

237 This process yields 162 monthly mean dynamic heights covering the period March 2000

238 to August 2013. Dynamic heights are used to calculate geostrophic velocities relative to

239 the reference level of $1000 \mathrm{dbar}$ on a $0.5^{\circ}$ longitude by $0.5^{\circ}$ latitude grid from $5^{\circ} \mathrm{S}$ to

$24050^{\circ} \mathrm{S}$. Absolute geostrophic velocity is then estimated using drift velocities obtained from

241 the trajectories of 825 Argo and WOCE floats, which were active from December 9, 1992

242 to February 20, 2014 and drifted in the pressure range of 800 to 1100 dbar. These drift

243 velocities, and the associated pressures, are used to derive gridded fields of the absolute

244 velocity (Schmid, 2014). The gridded monthly mean profiles of geostrophic relative

245 velocity are then referenced to the monthly mean float-derived absolute velocities, when

246 available. If no monthly mean absolute velocity estimate is available at a given grid point,

247 then the climatological absolute velocity is used. The resulting monthly mean absolute 
248 geostrophic velocity fields are then averaged to generate a 3-D field of the long-term

249 mean of the horizontal velocity.

250

251 The long-term mean gridded Argo-derived absolute velocity field at 2000 dbar (within

252 the upper layer of the NADW) is shown in Figure 3 (top panel). This high-resolution

253 velocity field is a bit overwhelming, so for illustration purposes polygons were defined

254 around each of the two bands of deep flow discussed herein and the vectors within those

255 polygons were colored to highlight the predominant flow of interest for the present

256 discussion. In the boundary current polygon, the grid cells where the meridional velocity

257 is negative (southward) were highlighted in red. In the polygon for the interior pathway,

258 grid cells where the zonal velocity is positive (eastward) were highlighted in blue. In

259 order to provide a measure of the significance of the velocity field, a t-test is applied to

260 detect which zonal velocity component is too small to be significant with respect to a

$26195 \%$ confidence interval. Vectors where the zonal component of the velocity fails this

262 criteria are excluded from the top panel of Figure 3. A similar t-test has also been applied

263 to the meridional velocity component to ensure that the southward flows along the

264 western boundary are significant. This was found to be the case with the exception of a

265 very small band about $37^{\circ} \mathrm{S}$, where the influence of the Brazil Malvinas confluence is

266 large and the flow near the boundary has a relatively large (and significant) zonal 
component.

269 South of the Vitória-Trindade Ridge (Figure 3, top panel), two branches of the flow are

270 evident. The dominant branch is a strong southward flow (highlighted in red) along the

271 coast of South America. This flow separates from the boundary at $38^{\circ} \mathrm{S}$, the region of the

272 Brazil-Malvinas Confluence, and continues southward all the way to $45^{\circ} \mathrm{S}$. The Argo

273 velocities also show eastward flow into the interior along roughly $22^{\circ} \mathrm{S}$ consistent with

274 the spreading of the NADW towards the center of the basin; this signal is not as clear as

275 the southward flow, however it is strongly supported by the CFC data (Figure 2). Some

276 details of the meridional and vertical structure of the eastward flow along this pathway

277 (highlighted in blue) are given in Figure 3 (bottom panel) which shows the zonal velocity

278 in $\mathrm{cm} \mathrm{sec}^{-1}$ obtained from the Argo product along $25^{\circ} \mathrm{W}$ from $10^{\circ}$ to $30^{\circ} \mathrm{S}$. The figure

279 shows the evidence of two eastward jets at this longitude between $18^{\circ}$ and $25^{\circ} \mathrm{S}$. A jet

280 with a higher eastward velocity (maximum of $3.4 \mathrm{~cm} \mathrm{sec}^{-1}$ at $2000 \mathrm{~m}$ ) is observed

281 between $18^{\circ} \mathrm{S}$ and $20^{\circ} \mathrm{S}$ while the second eastward jet to the south of it, between $21^{\circ} \mathrm{S}$ and

$28224^{\circ} \mathrm{S}$, is observed to have a maximum eastward velocity of $1.7 \mathrm{~cm} \mathrm{sec}^{-1}$ at $2000 \mathrm{~m}$ at

$28322.5^{\circ} \mathrm{S}$. These two eastward jets are located in the region where the CLIVAR water

284 properties indicate the presence of NADW crossing $25^{\circ} \mathrm{W}$ (Figure 2). The analysis also

285 shows two westward flows at around $12^{\circ}$ and $16^{\circ} \mathrm{S}$, the southern one possibly

286 representing part of a recirculation that may result in enhanced mixing of waters on this

287 pathway. Also there is a very weak indication (at around $19^{\circ} \mathrm{S}, 8^{\circ} \mathrm{W}$ ) of a northward

288 transport that may feed back a small potion of the water into these westward flows

289 (Figure 3 top panel). However this small pathway is not connected by significant vectors 
290 and as such it is not clear how it fits in the overall circulation pattern. Nevertheless it

291 appears that most of the significant flow continues towards the east. Eastward of the

292 Walvis Ridge $\left(\sim 0^{\circ} \mathrm{E}\right)$, the Argo velocity product does not show a clear picture of a

293 continuous jet (Figure 3, top panel). This may be likely due to the high mesoscale motion

294 in and northwest of the Cape Basin.

295

296 3. The Ocean General Circulation Model for the Earth Simulator (OFES)

297 Even with the improved data sets currently available for this study (updated hydrographic

298 data, Argo float drift velocities), the data that can be used to study NADW pathways in

299 the South Atlantic is still fairly limited. As such, a high quality ocean model can provide

300 valuable circulation information. OFES is a massively parallelized implementation of

301 version 3 of the NOAA/GFDL Modular Ocean Model (MOM3) run by the Japan Agency

302 for Marine-Earth Science and Technology (JAMSTEC). The model equations have been

303 discretized on a Mercator B grid with a horizontal resolution of $0.1^{\circ}$ and 54 vertical z-

304 levels. The simulation used in this study was spun up for 50 years with a monthly

305 climatology of atmospheric forcing derived from the National Center for Environmental

306 Prediction-National Center for Atmospheric Research (NCEP-NCAR) reanalysis

307 (Masumoto et al., 2004), and then forced with daily mean NCEP-NCAR reanalysis data

308 from January 1950 to December 2006 (Sasaki et al., 2008). OFES fields are publically

309 available for a 27-year time period from January 1980 to December 2006 as snapshots at 
310 3-day intervals. OFES reproduces the large-scale sea surface height variability in the

311 South Atlantic well when compared to altimetric data (e.g., Dong et al., 2011; Perez et al.,

312 2011). It has recently been used in various studies aimed at characterizing the time-mean

313 and time-variability of components of the AMOC in the South Atlantic (e.g. Dong et al.,

314 2011; Perez et al., 2011, van Sebille et al., 2012).

315

316 The OFES model has been validated in different regions of the global ocean by different

317 authors (Masumoto, 2010, and references therein). In the context of NADW pathways in

318 the South Atlantic, van Sebille et al. (2012) validated the velocity fields at the western

319 boundary of the South Atlantic between $5^{\circ} \mathrm{S}$ and $11^{\circ} \mathrm{S}$ by comparing sections of 27 -year

320 mean meridional velocity in OFES in the DWBC with data collected by moored current

321 meters (Schott et al., 2005) and, at $30^{\circ} \mathrm{S}$ with data from Lagrangian floats collected by

322 Hogg and Thurnherr (2005). They concluded that the extent, position, and strength of the

323 DWBC in OFES at these locations compare well with the available in situ observations at

324 that time.

325

326 In the present study, further validation is done by comparing fields from the OFES model

327 with hydrographic data collected on zonal sections along $5^{\circ} \mathrm{S}$ and $30^{\circ} \mathrm{S}$, and the model

328 output is also compared to the gridded World Ocean Atlas 2009 temperature and salinity 
329 climatology (WOA09; Locarnini et al., 2010), and the Argo data product discussed

330 earlier (Section 2.2). These data were used to validate the accuracy of the location of the

331 different water masses in the South Atlantic in the model and the total volume transport

332 of NADW that enters and exits the South Atlantic at various latitudes between $4.6^{\circ} \mathrm{S}$ and

$33335^{\circ} \mathrm{S}$.

334

335 Comparisons of WOA09 and OFES salinity sections in the South Atlantic show that the

336 boundaries of the neutral density levels $\left(27.9\right.$ and $\left.28.1 \mathrm{~kg} \mathrm{~m}^{-3}\right)$, which bracket the NADW,

337 are very similar in the model and in the observations. An example is Figure 4, which

338 shows zonal sections of the climatological mean salinity from the WOA09 (left), and

339 from the 27-year mean OFES model section (right), both along $30^{\circ} \mathrm{S}$. The lower panel of

340 Figure 4 shows the corresponding potential temperature/salinity diagram. In the interior

341 of the basin, the upper boundary of the NADW (neutral density 27.9) is at $1700 \mathrm{~m}$ both in

342 the model and the observations. Near the continental boundaries, the upper boundary of

343 the NADW is slightly deeper in the observations ( $2000 \mathrm{~m}$ in the west and $1500 \mathrm{~m}$ in the

344 east for the observations, compared with $1800 \mathrm{~m}$ and $1500 \mathrm{~m}$ for the model) (Figure 4

345 upper panel). Differences in the depth of the lower boundary of NADW (neutral density

$34628.1 \mathrm{~kg} \mathrm{~m}^{-3}$ ) in the observations and the model are mostly related to differences in their

347 representations of bottom topography in particular at the Mid Atlantic Ridge (deeper 
348 white contours in Figure 4, upper panels). In addition, while the high salinity water on

349 the eastern side in the observations is captured well in the model, the agreement is not as

350 good in the west. The area bounded by the $S=34.8$ contour in the west is thicker in the

351 observations than in the model. A potential temperature-salinity (T/S) comparison

352 (Figure 4, lower panels) indicates that at $30^{\circ} \mathrm{S}$ the model is more saline (35.1) than the

353 observations (34.8) for upper NADW with neutral density between 27.9 and $28 \mathrm{~kg} \mathrm{~m}^{-3}$,

354 but with overall similar $\mathrm{T} / \mathrm{S}$ structure along the $28.1 \mathrm{~kg} \mathrm{~m}^{-3}$ neutral density contour.

355

$356 \quad 3.1$ Lagrangian analysis

357 As mentioned in the Introducion, van Sebille et al. (2012) examined the pathways of

358 NADW in the South Atlantic in the OFES model using Lagrangian pathways. In their

359 experiment, van Sebille et al. (2012) focused their analysis on the connectivity between

360 the DWBC and the Cape Basin.

361 In this paper, we used the simulated float database produced by van Sebille et al. (2012)

362 to further examine the primary NADW pathway in the DWBC along the South American

363 coast as well as the interior pathway. A brief description of the procedure they used is as

364 follows: Float deployments were simulated along a grid at $5^{\circ} \mathrm{S}$ whenever the local

365 instantaneous transport within the grid cell is southward. The grid spanned the full width 
366 of the South Atlantic between $1000 \mathrm{~m}$ and $3500 \mathrm{~m}$ depth and had $100 \mathrm{~m}$ vertical spacing.

367 Since most southward transport is carried by the DWBC, the horizontal grid spacing was

$3680.1^{\circ}$ in the DWBC west of $34^{\circ} \mathrm{W}$ and $0.5^{\circ}$ in the rest of the basin. For a total of 5 years,

369 one simulated float was released every 3 days. The vast majority of these floats are within

370 the NADW layer (van Sebille et al., 2012). Each float was assigned a transport equal to

371 the volume flux (velocity times area) through the grid cell in which it starts. After release,

372 the floats were tracked forward with a fourth order Runge-Kutta integration scheme as

373 implemented in the Connectivity Modeling System (CMS, Paris et al., 2013) using

374 snapshots of the OFES velocity fields with 3-day resolution. Advection of a float was

375 terminated when the float rises above $500 \mathrm{~m}$ depth, or when the float left the region

376 bounded on the north by $5^{\circ} \mathrm{S}$, at the south by $45^{\circ} \mathrm{S}$, and on the east by $17^{\circ} \mathrm{E}$. At the end of

377 the 27-year run, the model output was looped to produce a longer time series (300 years)

378 for forward integration of the simulated float tracks.

379 In this section, these $100,000+$ synthetic float tracks are further analyzed to show the

380 main pathway of the NADW along the continental slope of South America as well as the

381 interior pathway indicated by hydrographic, tracers, and Argo observations discussed in

382 Section 2. Transport estimates indicate that approximately $13.2 \mathrm{~Sv}$ (with a standard

383 deviation of $3.1 \mathrm{~Sv}$ ) are carried southward of $5^{\circ} \mathrm{S}$ across the entire basin in the depth 
384 range where the float were deployed (1000 to $3500 \mathrm{~m}$ ). This result is in agreement with

385 the value obtained from the hydrographic data collected along the WOCE A07 line (12.6

$386 \mathrm{~Sv}$ southward between neutral densities 27.9 to $28.1 \mathrm{~kg} \mathrm{~m}^{-3}$, see section 4). Lagrangian

387 particle backtracking (i.e. tracing particle pathways backward in time to determine where

388 the trajectories started) from points further south indicates that most of this south-

389 southeastward flow originates west of $30^{\circ} \mathrm{W}$ along $5^{\circ} \mathrm{S}$ ( $90 \%$ of the total virtual floats).

390

391 The synthetic float trajectories illustrate the very eddy-rich nature of the flows in the

392 South Atlantic. To focus on the primary pathways, the trajectories of the synthetic floats

393 that cross $5^{\circ} \mathrm{S}$ are then followed for two different pathways. In the first pathway, the

394 Lagrangian flow that crosses $30^{\circ} \mathrm{S}$ west of $30^{\circ} \mathrm{W}$ and continues south west of $40^{\circ} \mathrm{W}$ is

395 tracked and the transport is estimated. Examples of some of the floats that follow this

396 pathway are shown in Figure 5, top panel. The total transport carried by those

397 trajectories estimated following the procedure outlined in van Sebille et al. (2012) is

398 approximately $9.4 \mathrm{~Sv}$ (with a standard deviation of $4.2 \mathrm{~Sv}$ ) or $71 \%$ of the total southward

399 transport across $5^{\circ} \mathrm{S}$. A second pathway is defined by synthetic floats crossing $5^{\circ} \mathrm{S}$ west

400 of $30^{\circ} \mathrm{W}$ that continue towards the Cape Basin directly beneath the Agulhas Ring

401 corridor, crossing $17^{\circ} \mathrm{E}$ with the constraint of previously passing through the region

402 bounded by $20^{\circ}$ and $30^{\circ} \mathrm{S}$ and by $10^{\circ}$ and $9^{\circ} \mathrm{W}$ (examples shown in Figure 5, bottom 
403 panel). This is the interior pathway observed by the hydrographic, tracers, and Argo

404 observations. The transport associated with this pathway is approximately $2.9 \mathrm{~Sv}$ (with a

405 standard deviation of $1.4 \mathrm{~Sv}$ ). This is approximately $22 \%$ of the simulated float transport

406 in the NADW. These estimates are in agreement with those previously obtained by van

407 Sebille et al. (2012) who calculated that of the 15.0 Sv net southward transport crossing

$4085^{\circ} \mathrm{S}$, almost all of which is in the NADW density range, 10.2 Sv leaves the South Atlantic

409 across the southern boundary at $45^{\circ} \mathrm{S}$. They also calculated that $3.6 \mathrm{~Sv}$ exits across the

410 Agulhas section at $17^{\circ} \mathrm{E}$ with the remaining floats recirculating in the basin and staying in

411 the domain for a very long time (more than 300 years).

412

413 The present analysis of the synthetic Lagrangian floats leads to the conclusion that the

414 main pathway along which the NADW spreads into the South Atlantic is along the

415 continental shelf of South America, in the southward DWBC. The second pathway

416 crosses the Atlantic in agreement with that described by van Sebille at al. (2012) and with

417 the observational findings presented in Section 2.

418

$419 \quad 3.2$ Eulerian analysis

420 In this present analysis, OFES fields are also analyzed using more traditional Eulerian

421 methods that allow direct comparison with observations. The objective of the analysis is 
422 to quantify the associated Eulerian transports and to look at the variability of the NADW

423 pathways at different levels in the model and compare and contrast the Eulerian results

424 with the Lagrangian results.

425

\section{$426 \quad 3.2 .1$ Kinetic energy variability}

427 In order to provide a better picture of the energy distribution and the characteristic of the

428 flow, the mean velocity magnitude and eddy kinetic energy (EKE) in the model were

429 calculated at different depths within the NADW layer: $1700 \mathrm{~m}$ (the upper boundary of

430 NADW), $2500 \mathrm{~m}$ (the NADW core depth), and $3600 \mathrm{~m}$ (the lower boundary of NADW).

431 Examples are shown for the two upper depths in Figure 6. The top panels show the

432 annual mean (model years 2001 to 2006) of the velocity magnitude at $1700 \mathrm{~m}$ (left) and

$4332500 \mathrm{~m}$ (right). The two bottom panels show the mean EKE at $1700 \mathrm{~m}$ (left) and at 2500

$434 \mathrm{~m}$ (right). Note, although not shown, the distribution of velocity and EKE at $3600 \mathrm{~m}$

435 figures are similar to those at $2500 \mathrm{~m}$.

436

437 The mean velocity magnitude (Figure 6, top panels) shows a steady and strong DWBC

438 flow following the continental shelf of South America at $1700 \mathrm{~m}$ depth from the equator

439 down to the Vitória-Trindade Ridge. At 2500 m, the mean DWBC flow is weaker but still

440 identifiable. This pattern is in agreement with the mean Argo horizontal velocity map 
441 (Figure 3). Analysis of the EKE fields (lower panels) reveals that the very energetic flow

442 variability entering the South Atlantic from the tropics is fairly tightly confined along the

443 western boundary (e.g. near $5^{\circ} \mathrm{S}$ ). Traveling southward, the region of flow variability

444 extends a little further offshore beginning around $8^{\circ} \mathrm{S}$. This increase in the EKE is

445 consistent with the DWBC breaking up into rings at this latitude as previously suggested

446 by Dengler et al. (2004) and Schott et al. (2005). When this flow reaches the Vitória-

447 Trindade Ridge at approximately $20^{\circ} \mathrm{S}$ the region of high variability stretches even

448 further offshore, which is consistent with the flow becoming even more energetically

449 eddy-dominated due to the interaction with the coastline and topographic ridge extending

450 offshore.

451

452 There is a signature of enhanced EKE stretching eastward across the basin towards the

453 Walvis Ridge (Figure 6, bottom panels), suggesting that these eddies may play a role in

454 transporting NADW into the interior (consistent with the simulated Lagrangian pathways,

455 the Argo velocity map, and the water mass maps). This feature is most clearly seen in the

456 EKE maps at $1700 \mathrm{~m}$, although there are hints at $2500 \mathrm{~m}$ as well. The EKE maps also

457 show a narrow tongue of higher variability close to the southern side of the Vitória-

458 Trindade Ridge and continental slope to the south, consistent with a more stable and

459 stationary DWBC flow reforming on the continental slope moving southward to about 
$46025^{\circ} \mathrm{S}$. This is confirmed by an increase in the mean horizontal velocity (top panels) south

461 of $25^{\circ} \mathrm{S}$ that remains confined along the western boundary until $40^{\circ} \mathrm{S}$ (again the signals

462 are stronger at $1700 \mathrm{~m}$ than $2500 \mathrm{~m}$ ). High levels of energy are also observed at the

463 eastern side of the basin in the region of the retroflection of the Agulhas Current and the

464 Agulhas Ring corridor (blue area in bottom panels of Figure 6 extending northwest from

465 the southern tip of Africa), and in the western side of the basin at the confluence of the

466 Brazil/Malvinas currents (blue area south of about $38^{\circ} \mathrm{S}$ near the western boundary). At

467 the core of the NADW, $2500 \mathrm{~m}$ (Figure 6 lower right panel), the EKE along the western

468 boundary is lower than at $1700 \mathrm{~m}$, but the western boundary signals are still much higher

469 than is found in the interior. At the lower boundary of the NADW, $3600 \mathrm{~m}$ (not shown),

470 the fields are less energetic than at $2500 \mathrm{~m}$ (Figure 6), however, the distribution of EKE

471 is similar.

472

473 Animations of the flows in the South Atlantic at all three levels analyzed in the model

474 (not shown) indicate that energetic mesoscale features propagating westward are

475 prevalent in the South Atlantic basin at these depths. In particular, signals generated in

476 the Agulhas Current region propagate northwestward into the interior along the model

477 ring corridor and in some cases reach the western boundary. To look at the westward

478 component of the propagation of the mesoscale signals in the basin, speed and EKE were 
479 plotted as a function of longitude for different latitudes and at different depths. An

480 example of this westward propagation can be seen in Figure 7 that shows a Hovmoller

481 diagram of the speed and the EKE along $25^{\circ} \mathrm{S}$ at $2500 \mathrm{~m}$ from 2001 to 2006 as a function

482 of longitude and time. The observed westward propagation has the characteristics of a

483 Rossby wave-like feature with estimated speeds of about 5 to $7 \mathrm{~cm} / \mathrm{s}$. The feature is

484 consistent with previous satellite and in situ observations of first baroclinic mode Rossby

485 waves (e.g., Osychny and Cornillon, 2004; Meinen and Garzoli, 2014).

486

487 3.2.2. Volume transports

488 During WOCE, a hydrographic section was occupied along 4.6 $\mathrm{S}$ (A07; Oudot, 1993;

489 Fajar et al., 2011). This latitude is close to the latitude of the simulated float deployments

490 in the experiment by van Sebille et al. (2012) discussed in Section 3.1. Data from the

491 WOCE section is used to obtain additional Eulerian validation of the OFES model flow

492 crossing this latitude, particularly within NADW density levels. Temperature and salinity

493 data from the WOCE section are used in conjunction with Argo drift velocities, at

494 nominally $1000 \mathrm{~m}$ depth, to calculate the absolute volume transport of NADW between

495 neutral density levels. From the temperature and salinity profiles, the geostrophic

496 velocities are calculated with a reference level of $1000 \mathrm{~m}$. Using the 3-D velocity

497 profiles derived from Argo in the South Atlantic (Section 2.2), the absolute velocity at 
$4981000 \mathrm{~m}$ between each pair of hydrographic sections is added to the geostrophic relative

499 velocities in order to obtain the absolute velocity. From the latter, the total integrated

500 NADW transport across the basin-wide section is estimated to be $-12.6 \mathrm{~Sv}$ (southward)

501 between neutral density layers 27.9 and $28.1 \mathrm{~kg} \mathrm{~m}^{-3}$. The corresponding mean transport

502 in the OFES model across $5^{\circ} \mathrm{S}$ between neutral densities 27.9 and $28.1 \mathrm{~kg} \mathrm{~m}^{-3}$ is $-13.9 \mathrm{~Sv}$

503 (southward). The standard deviation $(\sigma)$ of the mean values obtained from the 27-year

504 model output is $0.95 \mathrm{~Sv}$. This total integrated southward flow is mostly concentrated west

505 of $30^{\circ} \mathrm{W}$.

506

507 From the model velocity fields, meridional volume transports at different latitudes are

508 obtained between neutral density levels 27.9 and $28.1 \mathrm{~kg} \mathrm{~m}^{-3}$ corresponding to the

509 boundaries of the NADW. Results focusing on the meridional transport along the western

510 and eastern boundaries are summarized in Figure 8 and Table I. West of $30^{\circ} \mathrm{W}$, there is a

511 southward flow of $-13.9 \mathrm{~Sv}(\sigma=1.2 \mathrm{~Sv})$ at $10^{\circ} \mathrm{S}$ that is reduced to $-11.8 \mathrm{~Sv}(\sigma=0.7 \mathrm{~Sv})$ at

$51220^{\circ} \mathrm{S}$, the latitude of the Vitória-Trindade Ridge. Between $20^{\circ} \mathrm{S}$ and $30^{\circ} \mathrm{S}$, the coastline

513 makes an abrupt shift westward of roughly $5^{\circ}$ of longitude, so south of $25^{\circ} \mathrm{S}$ different

514 integration limits were used. The strong southward mean flow continues to be

515 concentrated on the western boundary following the continental shelf of South America.

516 From the $-12 \mathrm{~Sv}$ flowing southward at $25^{\circ} \mathrm{S},-9.0 \mathrm{~Sv}(\sigma=0.5 \mathrm{~Sv})$ can be found 
517 concentrated west of $40^{\circ} \mathrm{W}$ (as shown in Figure 8) while a smaller $-2.5 \mathrm{~Sv}$ is flowing

518 south more broadly between $30^{\circ} \mathrm{W}$ and $40^{\circ} \mathrm{W}$ (not shown in the figure for visual impact).

519 The southward transport at $35^{\circ} \mathrm{S}$ is $-7.5 \mathrm{~Sv}(\sigma=0.3 \mathrm{~Sv})$ and there is little indication of

520 additional southward flow offshore of $40^{\circ} \mathrm{W}$. The loss of transport between $30^{\circ} \mathrm{S}$ and

$52135^{\circ} \mathrm{S}$ seems to be primarily associated with a significant recirculation offshore of the

522 DWBC. Analysis of the model zonal velocity shows that the mean zonal transport is

523 westward $-1.3 \mathrm{~Sv}$ at $30^{\circ} \mathrm{S}$ and increase to $-3.0 \mathrm{~Sv}$ at $35^{\circ} \mathrm{S}$ which is an indication of the

524 recirculation consistent with the velocity field from the Argo floats shown in Figure 3.

525 Detailed analysis of the model (not shown) indicates that by $35^{\circ} \mathrm{S}$, there is a northward

526 volume transport of $1.5 \mathrm{~Sv}$ between $45^{\circ} \mathrm{W}$ and $40^{\circ} \mathrm{W}$, or roughly $20 \%$ of the strength of

527 the southward DWBC transport at that latitude.

528

529 Along the eastern boundary, east of $0^{\circ} \mathrm{E}$, only a very small volume of water crosses $5^{\circ} \mathrm{S}(-$

$530 \quad 0.2 \mathrm{~Sv}$ with a standard deviation of $0.03 \mathrm{~Sv}$ ) and the meridional volume transport near the

531 eastern boundary remains small with values of $-0.4(\sigma=0.01 \mathrm{~Sv})$ at $10^{\circ} \mathrm{S}$ and $0.2 \mathrm{~Sv}$ at

$53220^{\circ} \mathrm{S}(\sigma=0.03 \mathrm{~Sv})$. At $25^{\circ} \mathrm{S}$, the contributions from the interior of the basin begin to

533 augment the southward volume transport, reaching a maximum of $-4.6 \mathrm{~Sv}(\sigma=0.2 \mathrm{~Sv})$ at $53435^{\circ} \mathrm{S}$. 
536 Figure 8 can also be used to revisit a concept discussed earlier, namely that the DWBC

537 reforms in a coherent manner as a continuous boundary current south of the Vitória-

538 Trindade ridge at $20^{\circ} \mathrm{S}$. To illustrate this, the zero-lag correlations between the DWBC

539 meridional volume transport at $34.5^{\circ} \mathrm{S}$ integrated from coast to $44.5^{\circ} \mathrm{W}$ and $1700 \mathrm{~m}$ to

$5403000 \mathrm{~m}$ (over the 27-year record) and the meridional velocity at $2500 \mathrm{~m}$ depth were

541 determined at each OFES grid-point in the South Atlantic (color shading in Figure

542 8). Correlations are significant with $95 \%$ confidence, if they are larger than \pm 0.11

543 (assuming there are 12 independent samples per year over 27 years, or 324 independent

544 samples indicated with black and grey contours). Positive correlations (gray shading)

545 along the coast between roughly $22^{\circ} \mathrm{S}$ and $42^{\circ} \mathrm{S}$ indicate that the meridional flow between

546 these latitudes is coherent with the DWBC at $34.5^{\circ} \mathrm{S}$. This is consistent with the DWBC

547 having reformed into a steady flow in this region, as opposed to the eddy dominated flow

548 where the horizontal scales would be small enough that transport would be poorly

549 correlated beyond an eddy length scale. The negative correlations (cyan shading)

550 observed offshore of the strong positive correlation band are consistent with recirculation

551 of the DWBC waters in the model between roughly $37^{\circ} \mathrm{S}$ to $22^{\circ} \mathrm{S}$, just south of the

552 Vitória-Trindade ridge. Note that the pattern of the zero-lag correlations is not

553 significantly different from that of the maximum lagged correlations (not shown). 
555 In what follows, Eulerian volume transports obtained from the OFES model and available 556 observations across the basin and at the boundaries are analyzed at $5^{\circ} \mathrm{S}, 30^{\circ} \mathrm{S}$, and $34.5^{\circ} \mathrm{S}$

557 and compared with the Lagrangian transports estimated by van Sebille et al. (2012).

558 Estimates of the Eulerian volume transports are computed in two ways: integrated within 559 the neutral density range 27.9 and $28.1 \mathrm{~kg} \mathrm{~m}^{-3}$, the defined boundaries of NADW; and 560 integrated between 1000 and $3500 \mathrm{~m}$, the depth span over which the synthetic Lagrangian

561 floats were launched by van Sebille et al. (2012). Results are shown in Table I; negative 562 numbers indicate southward flow. Column 1 (black numbers) are the Eulerian transports 563 estimated from the OFES model between density levels 27.9 to $28.1 \mathrm{~kg} \mathrm{~m}^{-3}$. In the same 564 column results are compared with estimates previously discussed obtained from WOCE 565 A07 CTD data coupled with Argo data collected along nominally $5^{\circ} \mathrm{S}$, and with those 566 obtained by other observational systems in the area: from a CLIVAR A10 CTD section 567 collected along $30^{\circ} \mathrm{S}$, and from the average of the values obtained from a series of 568 expendable bathythermograph (XBT) transects conducted nominally along $35^{\circ} \mathrm{S}$ and 569 analyzed jointly with hydrographic and Argo data (see Garzoli et al., 2013) (called 570 "combined observations" in the Table). Column 2 show the volume transports estimated 571 from 1000 to $3500 \mathrm{~m}$ in a Eulerian reference frame, and column 3 the Lagrangian 572 transports from simulated floats deployed between 1000 and $3500 \mathrm{~m}$ following van 573 Sebille et al. (2012). Overall, there is agreement between model results and observations.

574 Across $5^{\circ} \mathrm{S}$ basin-wide, there is very good agreement between the basin wide transports 575 determined between neutral densities 27.9 and $28.1 \mathrm{~kg} \mathrm{~m}^{-3}(-13.9 \mathrm{~Sv}, \sigma=0.96$ from the 576 model, -12.6 Sv from observations). The simulated Lagrangian estimate of the flow at 
$5775^{\circ} \mathrm{S}$ in the 1000 to $3500 \mathrm{~m}$ layer $(-13.2 \mathrm{~Sv}, \sigma=3.2 \mathrm{~Sv})$ is similar to the Eulerian

578 simulated transport between neutral density levels $(13.9 \mathrm{~Sv}, \sigma=0.96 \mathrm{~Sv})$. However, the

579 Eulerian estimates from observations between 1000 and 3500 m (-21.4 Sv) are noticeably

580 larger than those obtained from the model $(-16.8 \mathrm{~Sv}, \sigma=1.1 \mathrm{~Sv})$; this could be an

581 indication of the model not capturing the circulation in the deep ocean (below $3000 \mathrm{~m}$ )

582 correctly.

583

584 When transports are estimated west of $40^{\circ} \mathrm{W}$ there is very good agreement between

585 estimates from the model and the observations. The difference between Eulerian and

586 Lagrangian results can be explained by analyzing the depth of the simulated float

587 trajectories, which suggests that even though the synthetic floats were launched between

5881000 and $3500 \mathrm{~m}$, the majority of the floats tended to occupy a more restricted depth

589 range from 1000 to less than $3000 \mathrm{~m}$.

590

591 At the eastern boundary there is good agreement between the model and observations in

592 Eulerian coordinates (Table I), but the relationship is the opposite of those observed near

593 the western boundary (see also Figure 8). For example, southward volume transport

594 across $34.5^{\circ} \mathrm{S}$ and east of $0^{\circ} \mathrm{E}$ in the model is larger when estimated between density

595 layers $(-4.6 \mathrm{~Sv}, \sigma=0.2 \mathrm{~Sv})$ than between 1000 and $3500 \mathrm{~m}(-2.8 \mathrm{~Sv}, \sigma=0.23 \mathrm{~Sv})$; a

596 similar, albeit smaller, difference is found in the observations $(-4.2 \mathrm{~Sv}, \sigma=1.9 \mathrm{~Sv}$ versus 
$597-3.7 \mathrm{~Sv}, \sigma=1.0 \mathrm{~Sv}$ ). This is because at the eastern boundary the fixed 1000-3500 $\mathrm{m}$ depth

598 range includes some of the northward flow of Antarctic Intermediate Water (AAIW)

599 above the NADW, and the result is a smaller net southward flow in the fixed depth

600 integral (e.g., Schmid et al., 2003).

601

602 In addition to the comparisons shown in the Table, one additional data set that can be 603 compared is from the pressure-equipped inverted echo sounders (PIES) deployed along

$60434.5^{\circ} \mathrm{S}$ west of $44.5^{\circ} \mathrm{W}$ (Meinen et al., 2012). The PIES transports calculated between

605 density levels 27.9 and $28.1 \mathrm{~kg} \mathrm{~m}^{-3}(-10.9 \mathrm{~Sv})$ is larger than the model result $(-5.7 \mathrm{~Sv}$, not

606 shown in the Table) when integrated to $44.5^{\circ} \mathrm{W}$. About $2 \mathrm{~Sv}$ of this difference can be

607 explained by a northward flow observed in the model, between $47^{\circ} \mathrm{W}$ and $49^{\circ} \mathrm{W}$ that is

608 not present in the PIES observations. Furthermore the agreement improves when the

609 volume transports are calculated between 1000 and 3500 m (PIES: -16.7 Sv; model: -14.0

$610 \mathrm{~Sv})$.

611

\section{4. Discussion and conclusions}

613 Lagrangian and Eulerian analysis of the OFES model, validated against

614 hydrographic/tracer, XBT, Argo and PIES data, provides a description of the pathways of

615 the DWBC as it flows through the South Atlantic, carrying NADW southward as the 
616 lower limb of the AMOC. From the Eulerian model analysis, it is estimated that

617 approximately $-13.9 \mathrm{~Sv}$ of water crosses $5^{\circ} \mathrm{S}$ flowing southward into the South Atlantic in

618 a layer limited by the neutral density surfaces 27.9 and $28.1 \mathrm{~kg} \mathrm{~m}^{-3}$. These density levels

619 correspond approximately to depths between $1700 \mathrm{~m}$ and $3000 \mathrm{~m}$, and are the boundaries

620 of the NADW ventilated with CFCs in the South Atlantic.

621

622 Re-analysis of the WOCE-era hydrographic data collected along $5^{\circ} \mathrm{S}$ in conjunction with

623 the Argo drift velocity field is in agreement with further analysis of the Lagrangian floats

624 advected for 300 years in OFES model following van Sebille et al. (2012). This analysis

625 indicates that $90 \%$ of the total floats that constitute the southward flow at $5^{\circ} \mathrm{S}$ originate

626 west of $30^{\circ} \mathrm{W}$. These results are obtained by backtracking the particles, and by the

627 Eulerian estimates of volume transport integrated across $5^{\circ} \mathrm{S}$.

628

629 Crossing $5^{\circ} \mathrm{S}$ and mostly concentrated west of $30^{\circ} \mathrm{W}$, the DWBC carries NADW along

630 the coast of South America and, in the model in agreement with previous results, breaks

631 up into rings near $8^{\circ} \mathrm{S}$, a region where the flow is mostly "non-steady." Analyses of the

632 eddy kinetic energy (EKE) at different depth levels in the model indicate high levels of

633 energy spreading further offshore south of $8^{\circ} \mathrm{S}$, consistent with the formation of energetic

634 rings. This "ring-dominated" flow continues southward to the Vitória-Trindade Ridge 
635 (near $20^{\circ} \mathrm{S}$ ). When the ring-dominated flow reaches the Vitória-Trindade Ridge, the

636 NADW is forced to flow to the east due to the topography. The branching of the flow in

637 this area is due to the preservation of potential vorticity (Zangenberg and Siedler, 1998).

638 Theory suggests that part of the along-slope southward flow turns into a zonal flow to the

639 east at the latitudes where the change in planetary vorticity is sufficiently large to

640 compensate for the change in potential vorticity due to the initial depth changes. In the

641 Southern Hemisphere, the Coriolis parameter is negative and the water column rotates

642 clockwise with increasing depth.

643

644 The model suggests that about $22 \%$ of the NADW flows eastward from the western

645 boundary into the interior South Atlantic. WOCE and CLIVAR-era CFC observations

646 give a clear pathway eastward roughly underlying the Agulhas Ring corridor, and

647 extending over a fairly broad latitude range (Figures 1 and 2). The Argo velocity field in

648 the upper NADW layer does not indicate a robust mean pathway for this eastward flow;

649 rather it is characterized by several meanders (Figure 3) and relatively weak mean

650 eastward jets. As there is a broad latitudinal distribution of properties extending eastward

651 into the interior and the complex Argo velocity mean picture is not particularly

652 suggestive of a narrow corridor of NADW transfer under the Agulhas Ring corridor, it is

653 possible that more than one mechanism is involved in the transfer of ventilated NADW 
654 properties to the east near $20^{\circ} \mathrm{S}$. Therefore, it is hypothesized that this southeastward 655 spreading of properties could result from a combination of the mechanism of eddy-

656 thickness flux divergence due to Agulhas ring decay, previously proposed and examined

657 by van Sebille et al. (2012), enhanced by the clearly highly energetic eddy field at the

658 Vitória-Trindade ridge and eastward jets observed in the velocity field.

659

660 The most prevalent motion noted in the animations of the ocean model velocity fields at

661 three depths (not shown, but this can be inferred from the connectivity of the elevated

662 EKE regions in the Cape Basin to Vitoria-Trindade Ridge in Figure 6, and Hovmoller

663 diagrams in Figure 7) associated with the upper boundary, core, and lower boundary of

664 NADW is a strong northwestward propagation consistent with the westward propagation

665 characteristics of Rossby Waves. It is hypothesized that this westward propagation

666 interacting with the mean circulation field may be the reason why south of the Vitória-

667 Trindade Ridge most of the flow ( $71 \%$ in the model) returns to the continental slope, as

668 a more steady flow, forming the main branch of the DWBC south of the ridge. However,

669 a detailed analysis of this complicated eddy-mean flow interaction is beyond the scope of

670 the present study and is a topic for future research.

671

672 At $34.5^{\circ} \mathrm{S}$, the DWBC meridional volume transport between the coast and $44.5^{\circ} \mathrm{W}$ and 
673 from 1000 to $3500 \mathrm{~m}$ is about $-14 \mathrm{~Sv}$ in the model. This model transport is close to an

674 estimate of $-14.5 \mathrm{~Sv}$ from hydrographic data collected at $30^{\circ} \mathrm{S}$. Further analysis of the

675 model trajectories (not shown) indicates that after crossing $34.5^{\circ} \mathrm{S}$, a small amount (about

$6761 \mathrm{~Sv}$ ) of NADW flows towards the east at the latitude where the Malvinas Current turns

677 offshore $\left(\sim 38^{\circ} \mathrm{S}\right)$, in agreement with previous results from van Sebille et al. (2012). The

678 rest of the flow continues south to approximately $45^{\circ} \mathrm{S}$ where it joins with the eastward

679 flowing Antarctic Circumpolar Current.

680

681 Eulerian volume transport estimates obtained from the velocity field of the OFES model

682 between 27.9 and 28.1 neutral density levels (Figure 8) indicate that about $2 \mathrm{~Sv}$ of

683 NADW does not leave the South Atlantic as NADW. This is consistent with previous

684 modeling and observational results (Garzoli and Matano, 2011), which found that in the

685 Brazil-Malvinas Confluence region approximately $2.6 \mathrm{~Sv}$ of water is transformed from

686 NADW to AAIW.

687

688 Based on the available observations and the model analysis, we conclude that the NADW

689 follows two different pathways south of $5^{\circ} \mathrm{S}$. The main pathway $(\sim 71 \%)$ is southward in

690 the DWBC flowing along the coast of South America. A smaller portion ( 22\%) flows

691 eastward towards the interior of the basin. Better understanding of the pathways of the 
692 lower limb of the AMOC will be crucial for quantifying the fluxes of heat, fresh water

693 and $\mathrm{CO}_{2}$ through the South Atlantic. Furthermore, for understanding variations of the

694 AMOC, detailed knowledge of temporal changes of the pathways as well as what

695 mechanisms control those variations will be necessary.

696

697 Acknowledgements

698 This research was carried out in part under the auspices of the Cooperative Institute for

699 Marine and Atmospheric Studies (CIMAS), a Cooperative Institute of the University of

700 Miami and the National Oceanic and Atmospheric Administration (NOAA), cooperative

701 agreement \#NA10OAR4320143. Additional support was provided by NOAA's Climate

702 Program Office under grant \# NA13OAR4310131, by the NOAA Southwest Atlantic

703 MOC project, and the Physical Oceanography Division of NOAA's Atlantic

704 Oceanographic and Meteorological Laboratory. Rana Fine thanks the Physical

705 Oceanography Program of the National Science Foundation for support. Erik van Sebille

706 was supported by the Australian Research Council via grant DE130101336. The OFES

707 simulation was conducted on the Earth Simulator under the support of JAMSTEC. The

708 authors are indebted to Yoshikazu Sasai and Ricardo Matano for providing output from

709 the OFES simulations. The authors would like the anonymous reviewers whose

710 comments helped to the submission of an improved manuscript. 


\section{References}

713 Arhan M., H. Mercier and Y-H Park, 2003: On the deep water circulation of the eastern

714 South Atlantic Ocean, Deep-Sea Res. I, 50, 889-916, doi:10.1016/S0967$715 \quad 0637(03) 00072-4$.

716 Bower, A. S, Lozier, M.S, Gary, S.F. and Böning, C.W, 2009: Interior pathways of the 717 North Atlantic meridional overturning circulation. Nature, vol. 459, no. 7244, pp $718 \quad 243-247$.

719 Bryden, H. L., B. A. King, G. D. McCarthy, 2011: South Atlantic overturning circulation $720 \quad$ at $24^{\circ}$ S. J. Mar. Res. 69 (1), 38-55.

721 CLS (1996): AVISO User Handbook for Merged TOPEX/POSEIDON products. CLS

722 Ref.: AVI-NT-02-101. See www.aviso.altimetry.fr/en/data/product-

723 information/aviso-user-handbooks.html

724 Dengler, M., F. A. Schott, C. Eden, P. Brandt, J. Fischer, and R. J. Zantopp, 2004: Break-

725 up of the Atlantic deep western boundary current into eddies at $8^{\circ} \mathrm{S}$, Nature, 432 , $726 \quad 1018-1020$.

727 Dong, S., M. Baringer, G. Goni, and S. Garzoli, 2011: Importance of the assimilation of 728 Argo Float Measurements on the Meridional Overturning Circulation in the South 729 Atlantic. Geophys. Res. Lett., 38, L18603, doi:10.1029/2011GL048982. 
730 Drijfhout, S. S., S. L. Weber, E. van der Swaluw, 2011: The stability of the MOC as

731 diagnosed from model projections for pre-industrial, present and future climates.

732 Clim. Dyn. 37, 1575-1586, doi:10.1007/s00382-010- 0930-z.

733 Fajar, N. M., F. F. Perez, A. Velo, and A. F. Rios, 2011: Data recovery of A06 and A07

734 WOCE cruises. Earth Syst. Sci. Data Discuss., 4, 99-122, doi:10.5194/essdd-4-99.

735 Fine, R.A. and R. Molinari, 1988: A continuous Deep Western Boundary Current be736 tween Abaco $\left(26.5^{\circ} \mathrm{N}\right)$ and Barbados $\left(13^{\circ} \mathrm{N}\right)$. A Rapid Response paper in Deep-Sea

$737 \quad$ Research, 35: 1441-1450.

738 Fine, R.A., M. Rhein and C. Andrié, 2002: Using a CFC effective age to estimate 739 propagation and storage of climate anomalies in the Deep Western North Atlantic

740 Ocean. Geophys. Res. Letts., 29(24), 2227, doi:10.1029/2002 GL015618.

741 Garzoli, S. L. and R. Matano, 2011: The South Atlantic and the Atlantic Meridional 742 Overturning Circulation. Deep-Sea Res., Part II, 58(17-18):1837-1847, 743 doi:10.1016/j.dsr2.2010.10.063.

744 Garzoli, S. L., M. O. Baringer, S. Dong, R. Perez, and Q. Yao, 2013: South Atlantic 745 meridional fluxes. Deep-Sea Res., Part I, 71:21-32, doi:10.1016/j.dsr.2012.09.003.

746 Hogg, N. G. and W. B. Owens, 1999: Direct measurement of the deep circulation within

747 the Brazil Basin. Deep-Sea Research II, 46, 335-353, doi:10.1029/2004/JC002311.

748 Hogg, N. G. and A. M. Thurnherr, 2005: A zonal pathway for NADW in the South 
Atlantic. Journal of Oceanography, 61(3): 493-507.

750 Johns, W. E., L. M. Beal, M. O. Baringer, J. R. Molina, S. A. Cunningham, T. Kanzow,

751 and D. Rayner, 2008: Variability of shallow and deep western boundary currents off

752 the Bahamas during 2004-05: Results from the $26^{\circ} \mathrm{N}$ RAPID-MOC array.

$753 \quad$ J.Phys.Oceanogr., 38, 605- 623.

754 Jullion, L., K. J. Heywood, A. C. Naveira Garabato, and D. P. Stevens, 2010: Circulation

755 and water mass modification in the Brazil-Malvinas confluence. J. Phys. Oceanogr.,

756 40, 845-864, doi: 10.1175/2009JPO4174.1.

757 Kieke, D., M. Rhein, L. Stramma, W. M. Smethie, Jr., J. L. Bullister and D. A. LeBel,

758 2007: Changes in the pool of Labrador Sea Water in the subpolar North Atlantic

759 related to changes in the upper North Atlantic circulation Geophysical Ressearch

$760 \quad$ Letters 34, LO6605, doi:10.1029/2006GL028959.

761 Koltermann, K. P., V. V. Gouretski and K. Jancke, 2011: Hydrographic Atlas of the

762 World Ocean Circulation Experiment (WOCE). Volume 3: Atlantic Ocean (eds. M.

763 Sparrow, P. Chapman and J. Gould). International WOCE Project Office,

$764 \quad$ Southampton, UK, ISBN 090417557X.

765 Locarnini, R. A., A. V. Mishonov, J. I. Antonov, T. P. Boyer, H. E. Garcia, O. K.

766 Baranova, M. M. Zweng, and D. R. Johnson, 2010: World Ocean Atlas 2009, Volume 
Lumpkin, R., and Speer, K., 2007: Global ocean meridional overturning. J. Phys.

771

772

773

774

775

776

777

778

779

780

781

782

783 j.dsr2.2012.07.036.

784 Meinen, C. and S. L. Garzoli, 2014: Attribution of Deep Western Boundary Current 785

Masumoto, Y., H. Sasaki, T. Kagimoto, N. Komori, A. Ishida, Y. Sasai, T. Miyama, T. Motoi, H. Mitsudera, K. Takahashi, H. Sakuma, and T. Yamagata, 2004: A fifty-year eddy-resolving simulation of the world ocean: preliminary outcomes of OFES (OGCM for the Earth Simulator), J. Earth Sim., 1, 35-56.

Masumoto, Y., 2010: Sharing the results of a high-resolution ocean general circulation model under a multi-discipline framework a review of OFES activities. Ocean Dyn., $60,633-652$.

Matano, R. P., and E. J. Beier, 2003: A kinematic analysis of the Indian/Atlantic interocean exchange. Deep-Sea Res. II. 50 (1), 229-249.

Meinen, C. S., W. E. Johns, S. L. Garzoli, E. van Sebille, D. Rayner, T. Kanzow, and M. O. Baringer, 2012: Variability of the Deep Western Boundary Current at $26.5^{\circ} \mathrm{N}$ during 2004-2009. Deep-Sea Res. Part II, 85:154-168, doi:10.1016/ variability at $26.5^{\circ} \mathrm{N}$. Deep Sea Research I, 90, 81-90, doi: 10.1016/ 
j.dsr.2014.04.016.

787 Molinari, R. L., R. A. Fine, W. D. Wilson, R. G. Curry, J. Abell, and M. S. McCartney, 788 1998: The arrival of recently formed Labrador Sea Water in the Deep Western 789 Boundary Current at $26.5^{\circ} \mathrm{N}$. Geophysical Research Letters, 25: 2249-2252.

790 Muiller, T. J., Y. Ikeda, N. Zangenberg, and L. V. Nonato, 1998: Direct measurements of 791 western boundary currents of Brazil between $20^{\circ} \mathrm{S}$ and $28^{\circ} \mathrm{S}$. J. Geophys. Res., 103, 792 $5429-5437$.

793 Oudot, C., 1993: Total CO2 and total alkalinity data obtained during the R/V L'Atalante 794 cruise in the Atlantic Ocean, (WOCE Section A06, 2 January-10 February 1993) 795 http://cdiac.ornl.gov/ftp/oceans/a06woce/, Carbon Dioxide Information Analysis 796 Center, Oak Ridge National Laboratory, US Department of Energy, Oak Ridge, 797 Tennessee, doi:10.3334/CDIAC/otg.WOCE A06 1993.

798 Osychny, V., and P. Cornillon, 2004: Properties of Rossby waves in the North Atlantic 799 estimated from satellite data, J. Phys. Oceanogr., 34(1), 61-76.

800 Paris, C. Helgers, J., van Sebille, E. and A. Srinivasan, 2013: Connectivity Modeling 801 System: A probabilistic modeling tool for the multi-scale tracking of biotic and 802 abiotic variability in the ocean. Environ. Modell. Softw., 42, 47-54.

803 Perez, R.C., S.L. Garzoli, C.S. Meinen, and R.P. Matano, 2011: Geostrophic Velocity 804 Measurement Techniques for the Meridional Overturning Circulation and 

1521.

807 Preu, B., F. J. Hernández-Molina, R. Violante, A. R. Piola, C. M. Paterlini, T. Schwenk, I. 808 Voigt, S. Krastel and V. Speiss, 2013: Morphosedimentary and hydrographic 809 features of the northern Argentine margin: the interplay between erosive, 810 depositional and gravitational processes and its conceptual implications, Deep-Sea 811 Res. I, 75, 157-174, doi: 10.1016/j.dsr.2012.12.013.

812 Provost, C., C. Escoffier, K. Maamaatuaiahutapu, A. Kartavtseff, and V. Garçon, 1999:

813 Subtropical mode waters in the South Atlantic Ocean, J. Geophys. Res., 104, $814 \quad 21,033-21,049$, doi:10.1029/1999JC900049.

815 Reid, J. L., 1989: On the total geostrophic circulation of the South Atlantic Ocean: Flow 816 patterns, tracers, and transports, Prog. Oceanogr., 23, 149-244.

817 Rimaud, J., S. Speich, B. Blanke, and N. Grima, 2012: The exchange of Intermediate

818 Water in the South East Atlantic: Water mass transformations diagnosed from the 819 Lagrangian analysis of a regional ocean model. J. Geophys. Res., 117, C08034, 820 doi:10.1029/2012JC008059.

821 Sasaki, H., M. Nonaka, Y. Masumoto, Y. Sasai, H. Uehara, and H. Sakuma, 2008: An 822 eddy-resolving hindcast simulation of the quasiglobal ocean from 1950 to 2003 on 823 the Earth Simulator, in High Resolution Numerical Modelling of the Atmosphere 

York.

826 Smethie, W.M., R.A. Fine, A. Putzka, E.P. Jones, 2000: Tracing the flow of North 827 Atlantic Deep Water using chlorofluorocarbons. Journal of Geophysical Research, $828 \quad 105: 14,297-14,234,2000$.

829 Schmid, C., Z. D. Garraffo, E. Johns, and S. L. Garzoli, 2003: Pathways and Variability 830 at intermediate depths in the tropical Atlantic. ed. by G. J. Goni and P. Malanotte831 Rizzoli. EOS, 68, 233-268.

832 Schmid, C., 2014: Mean vertical and horizontal structure of the subtropical circulation in 833 the South Atlantic from three-dimensional observed velocity fields. Deep-Sea Res.I, 834 (9), 50-71. DOI: 10.1016/j.dsr.2014.04.015.

835 Schmitz, W. J. and M. S. McCartney, 1992: On the North Atlantic circulation. Rev. of 836 Geophysics, 31, 29-50.

837 Schott, F. A., J. P. McCreary, and G. C. Johnson, 2004: Shallow overturning circulations 838 of the tropical-subtropical oceans. Earth Climate: The ocean-atmosphere interaction.

839 C. Wang, S.- P. Xie, and J.A. Carton, Eds, Geophys. Monogr., Amer. Geophys. $840 \quad$ Union, 261-304.

841 Schott, F. A., M. Dengler, R. J. Zantopp, L. Stramma, J. Fischer, and P. Brandt, 2005: 842 The shallow and deep western boundary circulation of the South Atlantic at 5_-11_S, 
844 Speich, S. ,B. Blanke, and W. Cai, 2007: Atlantic meridional overturning circulation and 845 the Southern Hemisphere supergyre. Geophysical Research Letters, Vol. 34, L23614, 846 doi:10.1029/2007GL031583.

847 Troupin, C., A. Barth, D. Sirjacobs, M. Ouberdous, J.-M. Brankart, P. Brasseur, M.

848 Rixen, A. Alvera Azcarate, M. Belouni, A. Capet, F. Lenartz, M.-E. Toussaint, 849 and J.-M. Beckers, 2012: Generation of analysis and consistent error fields using 850 the Data Interpolating Variational Analysis (Diva), Ocean Modelling, 52-53, 90$851 \quad 101$.

852 van Sebille, E., W. E. Johns, and L. M. Beal, 2012: Does the vorticity flux from Agulhas 853 rings control the zonal pathway of NADW across the South Atlantic?, J. Geophys. $854 \quad$ Res., 117, C05037, doi:10.1029/2011JC007684.

855 Wanninkhof, R., S. C. Doney, J. L. Bullister, N. M. Levine, M.Warner, and N. Gruber, 856 2010: Detecting anthropogenic CO2 changes in the interior Atlantic Ocean between 8571989 and 2005. Journal of Grophysical Research, Vol. 115, C11028, 858 doi:10.1029/2010JC006251.

859 Weiss, R. F., J. L. Bullister, R. H. Gammon, M. J. Warner, 1985: Atmospheric 860 chlorofluoromethanes in the deep equatorial Atlantic, Nature,314, 608-610.

861 Zangenberg, N., and G. Siedler, 1998: Path of North Atlantic Deep Water in the Brazil 


\section{Captions for the Figures}

865 Figure 1: Map of CFC-11 in pmol kg${ }^{-1}$ on neutral density level $27.9 \mathrm{~kg} \mathrm{~m}^{-3}$, the level of 866 the upper NADW, generated from WOCE-era data from 1992 to 1997. Brown

867

868 lines indicate highlighted WOCE lines: A10 zonal line along $30^{\circ} \mathrm{S}$, A16S meridional line at $25^{\circ} \mathrm{W}$ and $\mathrm{A} 13$ meridional line at $0^{\circ} \mathrm{E}$. The black dots indicate

869 locations of all of the other WOCE stations used to make this map.

870

871

872

873

874

875

876

877

878

879

880

881

882

883 Figure 3: Top panel: Velocity field at 2000 dbar derived from the Argo data. Red vectors 
highlight the southward to southwestward flow along the western boundary;

885

886

887

888

889

890

891

892

893

894

895

896

897

898

899

900

901

902

903

904

905

906

blue indicates the eastward velocity originating near the Vitória-Trindade ridge. Isobaths: 2000, 2500 and $3000 \mathrm{~m}$. Solid curves highlight the pathway of the DWBC along the South American coast. Dashed lines indicate regions where the pathway is less well defined as it moves to the interior of the basin. The meridional line indicates the location of the vertical section displayed in the lower panel. Areas with no vectors or shading indicate that velocities are too small to be significant with respect to a $95 \%$ confidence interval. Lower panel: Meridional-vertical structure of the eastward pathway in the top panel showing the zonal velocity in $\mathrm{cm} \mathrm{sec}^{-1}$ along $25^{\circ} \mathrm{W}$ from $10^{\circ}$ to $30^{\circ} \mathrm{S}$.

Figure 4: Top panels: zonal sections of the climatological mean salinity from World Ocean Atlas 2009 (WOA09, left), and from the 27-year mean OFES model section (right), both along $30^{\circ} \mathrm{S}$. White color contours in the upper panels indicate neutral density levels 27.9 and $28.1 \mathrm{~kg} \mathrm{~m}^{-3}$. The lower panels show the corresponding potential temperature/salinity diagrams from the WOA09 (left) and the model (right). Black contous indicate neutral density. Red indicates temperature and salinity values corresponding to the characteristics of the NADW (neutral densities 27.9 and $28.1 \mathrm{~kg} \mathrm{~m}^{-3}$ ).

Figure 5: Some examples of the two main pathways for synthetic floats launched in the NADW layer at $5^{\circ} \mathrm{S}$ west of $30^{\circ} \mathrm{W}$. Top panel: Floats that follow the western boundary, defined as floats that cross $30^{\circ} \mathrm{S}$ west of $40^{\circ} \mathrm{W}$ and leave the South Atlantic across $45^{\circ} \mathrm{S}$. Bottom panel: Floats that follow an interior pathway by leaving the South Atlantic across $17^{\circ} \mathrm{E}$ after having passed through a box 
defined by $9^{\circ}$ to $10^{\circ} \mathrm{W}$ and $20^{\circ}$ to $30^{\circ} \mathrm{S}$. The color shading indicates the depth of the float in meters.

909 Figure 6: Mean velocity magnitude in $\mathrm{cm} \mathrm{sec}^{-1}$ (top panels) and eddy kinetic energy (EKE) in $\mathrm{cm}^{2} \sec ^{-2}$ (bottom panels) calculated from the 2001 to 2006 OFES fields for two different depths: the upper boundary of the DWBC (1700 m, left) corresponding to NADW, and obtained from the OFES velocity fields. At $5^{\circ} \mathrm{S}$

924

925

926

927

928

929 and the core of the DWBC (2500 m, right). Color bars are velocity magnitude in $\mathrm{cm} \mathrm{sec}^{-1}$ (top panels) and eddy kinetic energy (EKE) in $\mathrm{cm}^{2} \mathrm{sec}^{-2}$ (bottom panels).

Figure 7: Hovmoller diagrams of the horizontal velocity magnitude in $\mathrm{cm} \mathrm{sec}^{-1}$ (left) and eddy kinetic energy (EKE) in $\mathrm{cm}^{2} \mathrm{sec}^{-2}$ (right) calculated from the 2001 to 2006 OFES fields across $25^{\circ} \mathrm{S}$ and at $2500 \mathrm{~m}$ depth, as a function of longitude and time. Color bars are velocity magnitude in $\mathrm{cm} \mathrm{sec}^{-1}$ (left) and eddy kinetic energy (EKE) in $\mathrm{cm}^{2} \mathrm{sec}^{-2}$ (right). The vertical line at approximately $14^{\circ} \mathrm{W}$ indicate no data due to the presence of the Mid Atlantic Ridge.

Figure 8: Volume transports between neutral density levels 27.9 and $28.1 \mathrm{~kg} \mathrm{~m}^{-3}$ the transport is integrated across the basin. At other latitudes, transports are calculated west of $30^{\circ} \mathrm{W}$ (from 5 to $25^{\circ} \mathrm{S}$ ) and west of $40^{\circ} \mathrm{W}$ at $30^{\circ}$ and $35^{\circ} \mathrm{S}$. At the eastern side of the ocean, volume transports are calculated east of $0^{\circ} \mathrm{E}$. The color shading show the zero-lag correlation between meridional velocity in the South Atlantic at a depth of $2500 \mathrm{~m}$ with the DWBC meridional volume transport along $34.5^{\circ} \mathrm{S}$. The color scale is the correlation value from 1.0 to -1.0 . Black and cyan contours show positive and negative correlations that are 
significant with $95 \%$ confidence.

931

\section{Caption for the Table}

933 Table I: Meridional volume transport in $\mathrm{Sv}\left(1 \mathrm{~Sv}=10^{6} \mathrm{~m}^{3} \mathrm{sec}^{-1}\right.$, negative indicates 934 southward), Numbers in parentheses correspond to the standard deviation. 935 Observed values (red) were obtained from: CTD and Argo observations at $5^{\circ} \mathrm{S}$, 936 CTD observations at $30^{\circ} \mathrm{S}, \mathrm{XBT}$ observations combined with CTD and Argo 937 floats data at $\sim 35^{\circ} \mathrm{S}$, and a line of PIES (pressure-equipped inverted echo 938 sounder) moorings along $34.5^{\circ} \mathrm{S}$. See text for more details.

939 Column 1: Eulerian transports estimated from the OFES velocity field between neutral densities 27.9 and $28.1 \mathrm{~kg} \mathrm{~m}^{-3}$ (black) and from observations (red) between the same density levels. Column 2: Eulerian transports estimated from the OFES velocity field between 1000 and $3500 \mathrm{~m}$ (black) and from observations (red) between the same levels. Column 3: Lagrangian transports estimated from the simulated float trajectory field for floats deployed between 1000 and $3500 \mathrm{~m}$. 


\begin{tabular}{|c|c|c|c|}
\hline & $\begin{array}{c}\text { Eulerian transports } \\
\text { estimated between } \\
\text { neutral density surfaces } \\
27.9 \text { to } 28.1 \text { ( } 1700 \text { to } \\
3000 \mathrm{~m})\end{array}$ & $\begin{array}{l}\text { Eulerian transports } \\
\text { estimated between } \\
\text { depth surfaces } \\
1000 \text { to } 3500 \mathrm{~m}\end{array}$ & $\begin{array}{l}\text { Lagrangian transports } \\
\text { estimated from } \\
\text { simulated floats } \\
\text { deployed between } \\
\text { depths of } 1000 \text { to } 3500 \\
\text { m }\end{array}$ \\
\hline \multirow[t]{2}{*}{$\begin{array}{l}\text { From model results from } \\
\text { coast to coast at } 5^{\circ} \mathrm{S} \text {. } \\
\text { From CTD and Argo } \\
\text { observations from coast to } \\
\text { coast at } 5^{\circ} \mathrm{S}\end{array}$} & -13.9 Sv (0.96) & -16.8 Sv (1.1) & $-13.2 \mathrm{~Sv}$ (3.2) \\
\hline & $\begin{array}{c}\text { From } 40.0^{\circ} \mathrm{W} \text { to the } \\
\text { west coast }\end{array}$ & $\begin{array}{c}\text { From } 40.0^{\circ} \mathrm{W} \text { to the } \\
\text { west coast }\end{array}$ & $\begin{array}{c}\text { From } 40.0^{\circ} \mathrm{W} \text { to the } \\
\text { west coast }\end{array}$ \\
\hline Model results at $34.5^{\circ} \mathrm{S}$ & $-7.5 \mathrm{~Sv}(0.3)$ & -16.4 Sv $(0.6)$ & $-9.4 \mathrm{~Sv}(4.2)$ \\
\hline \multirow{3}{*}{$\begin{array}{l}\text { From CTD observations at } \\
\qquad 30^{\circ} \mathrm{S} \\
\text { From combined observations } \\
\text { at } \sim 35^{\circ} \mathrm{S}\end{array}$} & $-8.2 \mathrm{~Sv}$ & $-14.5 \mathrm{~Sv}$ & $n / a$ \\
\hline & $-9.0 \mathrm{~Sv}(3.1)$ & $-19.5 \operatorname{Sv}(5.4)$ & $n / a$ \\
\hline & From $0^{\circ} \mathrm{E}$ to east coast & From $0^{\circ} \mathrm{E}$ to east coast & From $0^{\circ} \mathrm{E}$ to east coast \\
\hline $\begin{array}{c}\text { Model results at } 34.5^{\circ} \mathrm{S} \text {, } \\
\text { From combined observations } \\
\text { at } \sim 35^{\circ} \mathrm{S}\end{array}$ & $\begin{array}{l}-4.6 \text { Sv (0.2) } \\
-4.2 \text { Sv (1.9) }\end{array}$ & $-2.8 \mathrm{~Sv}(0.23)$ & $\begin{array}{c}-3.0 \mathrm{~Sv}(1.4) \\
\mathrm{n} / \mathrm{a}\end{array}$ \\
\hline
\end{tabular}




\section{Figure 1}

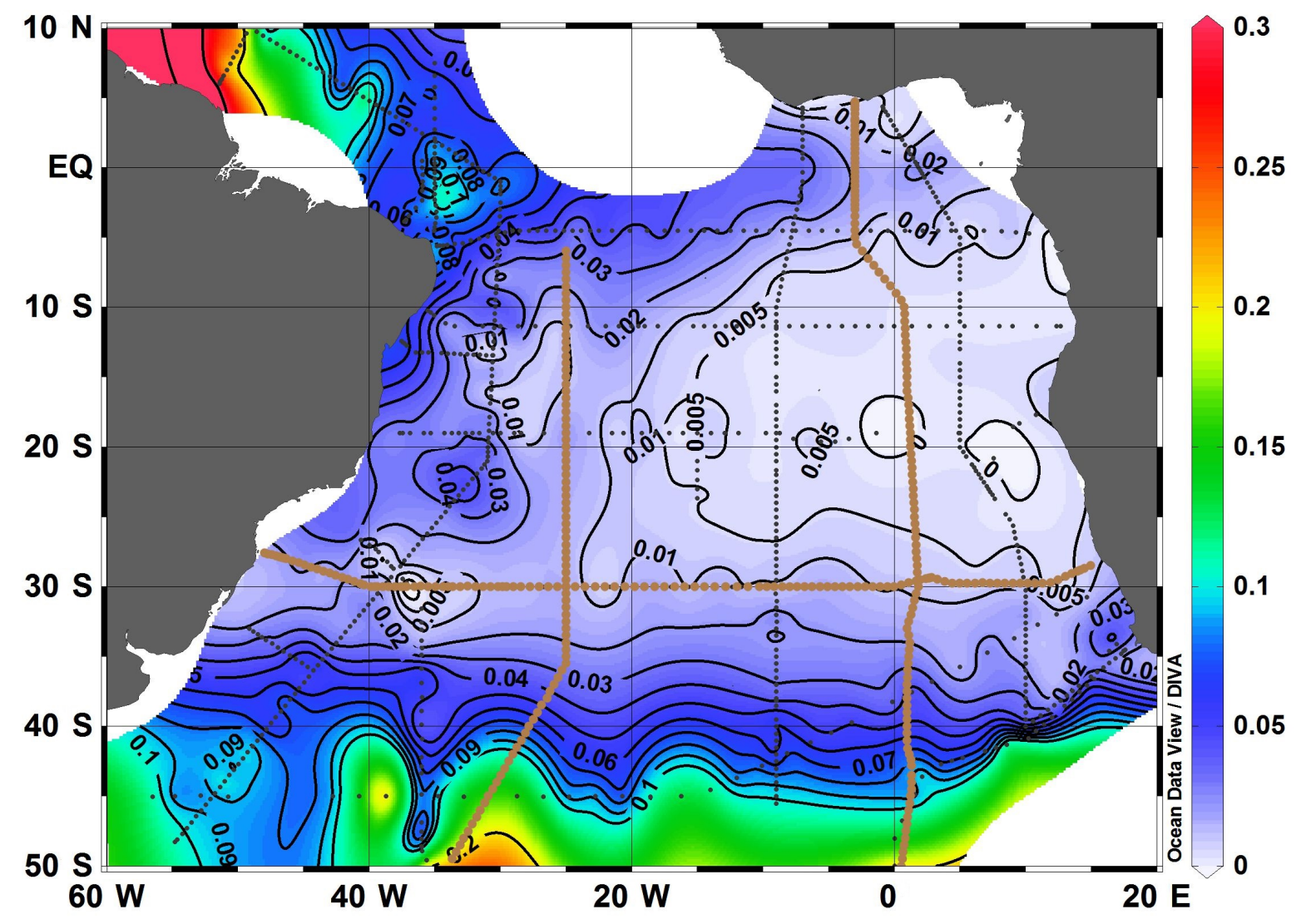


Figure 2
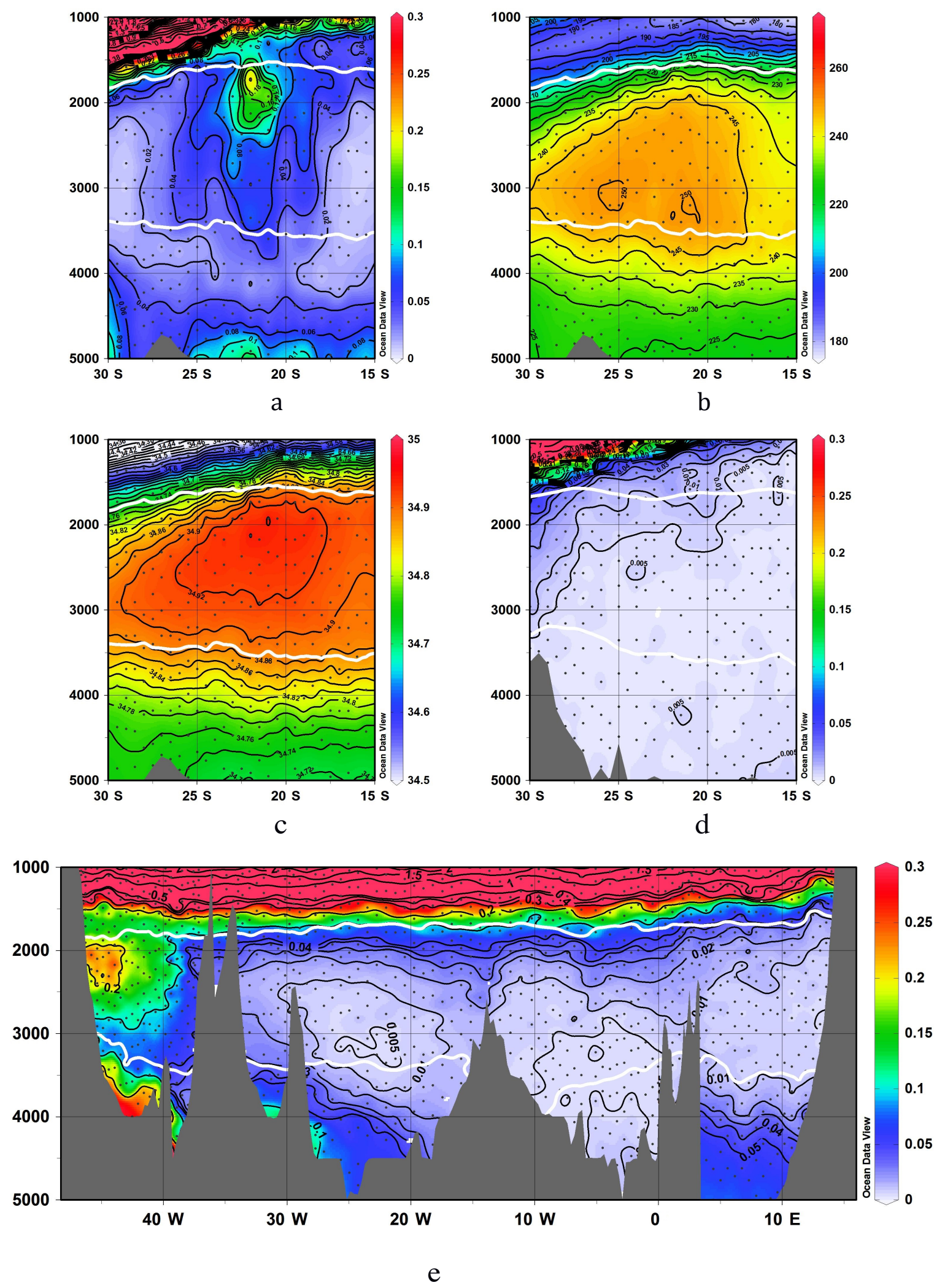
Figure 3
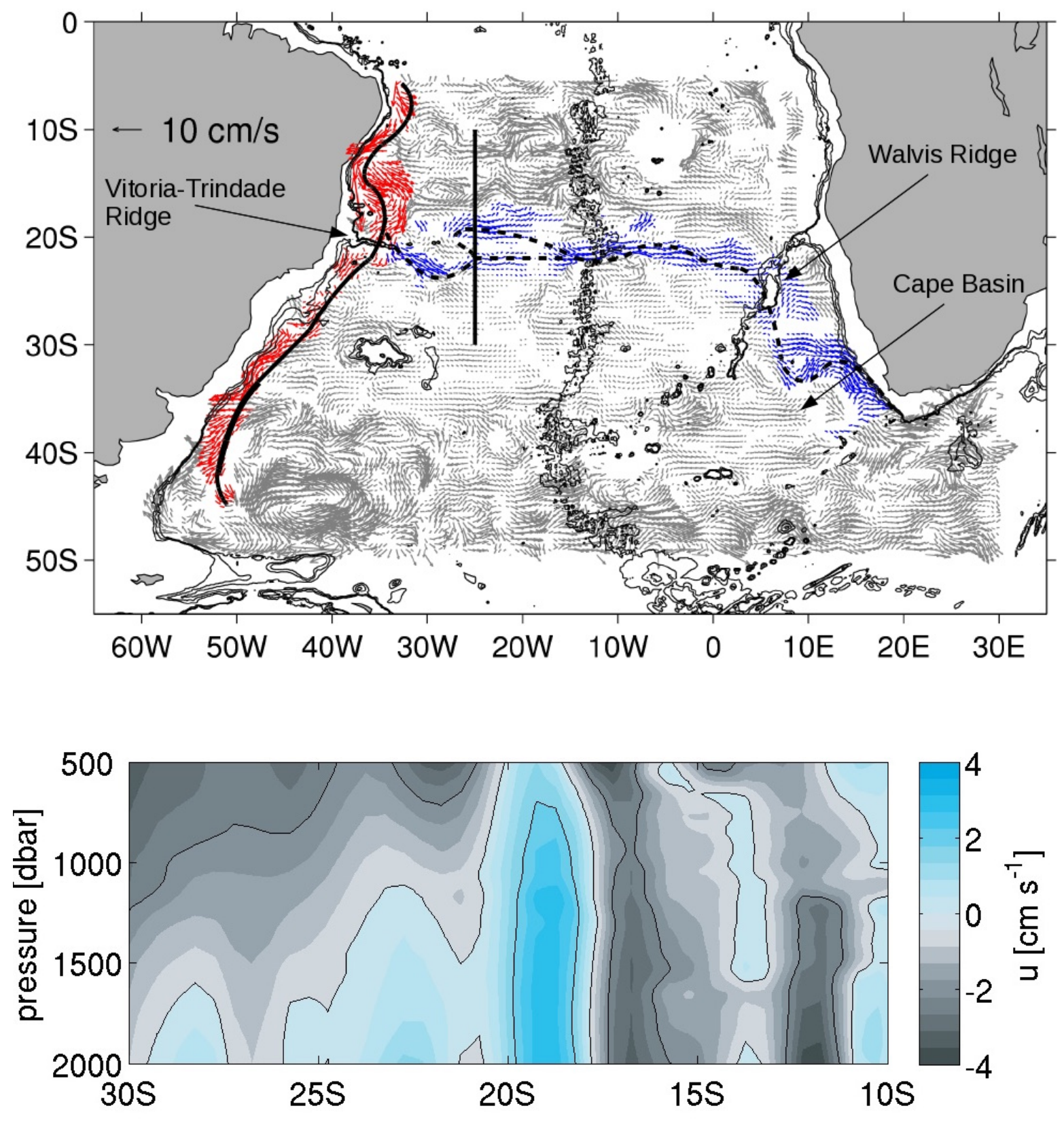


\section{Figure 4:}
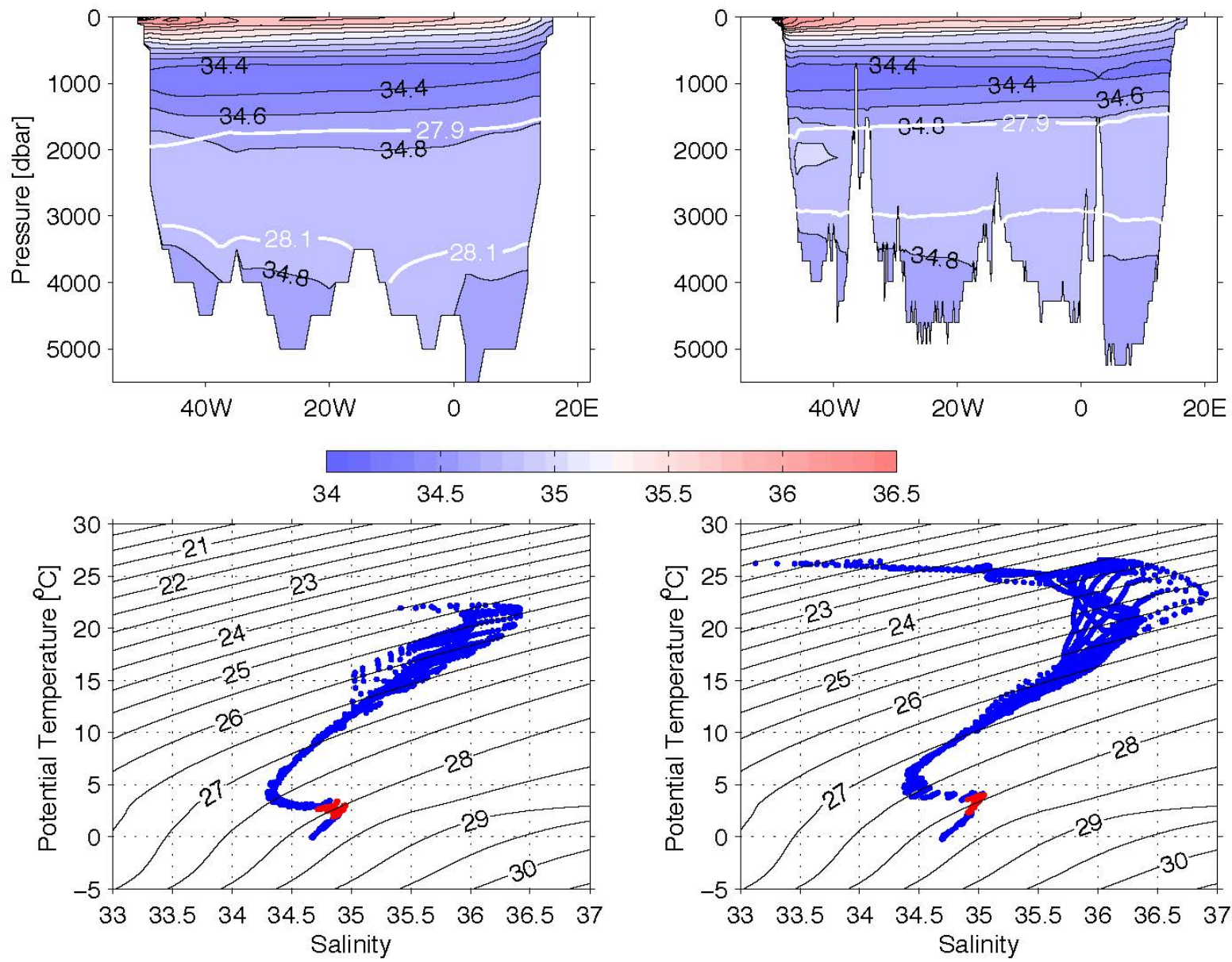
Figure 5
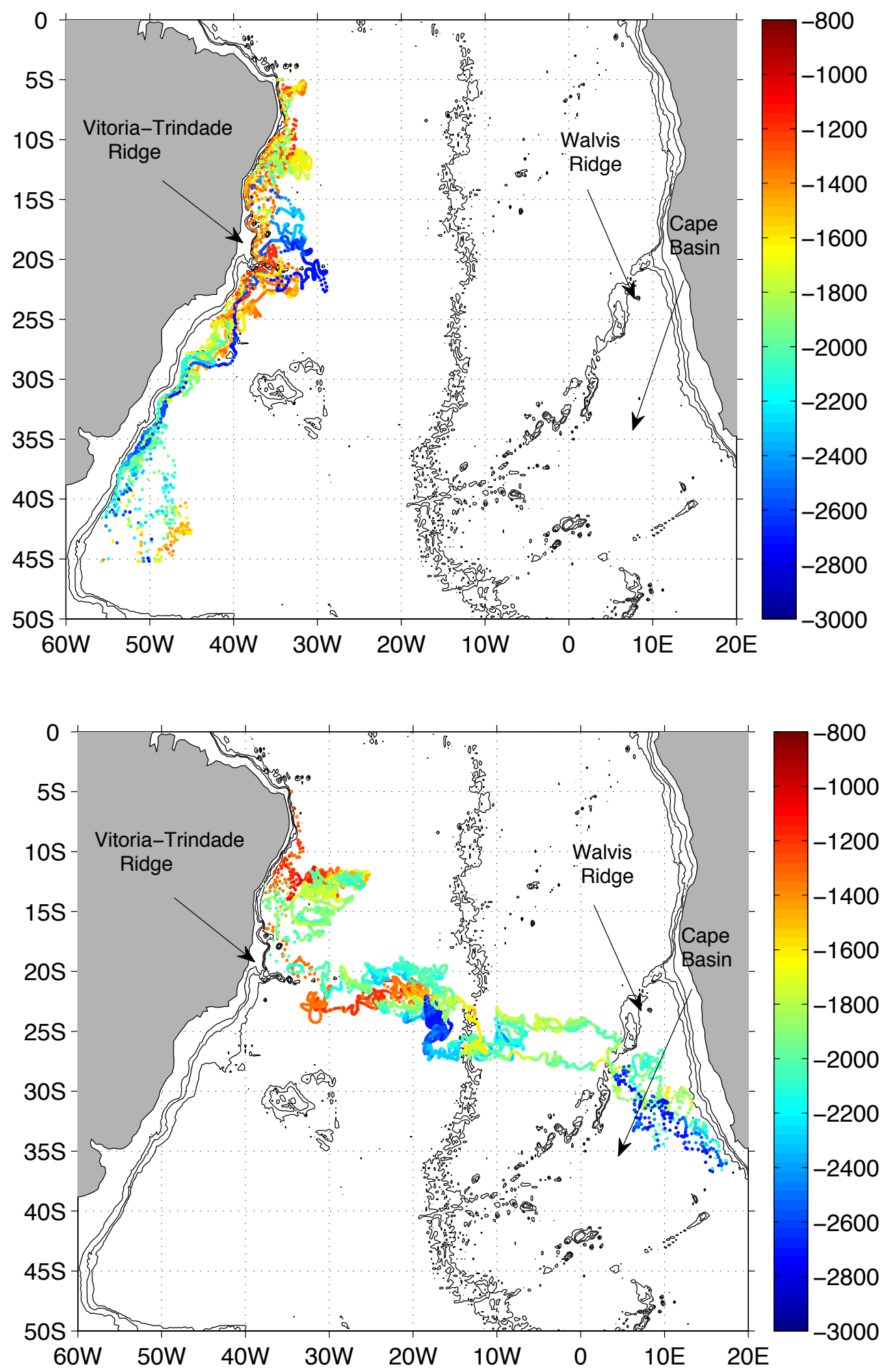
Figure 6
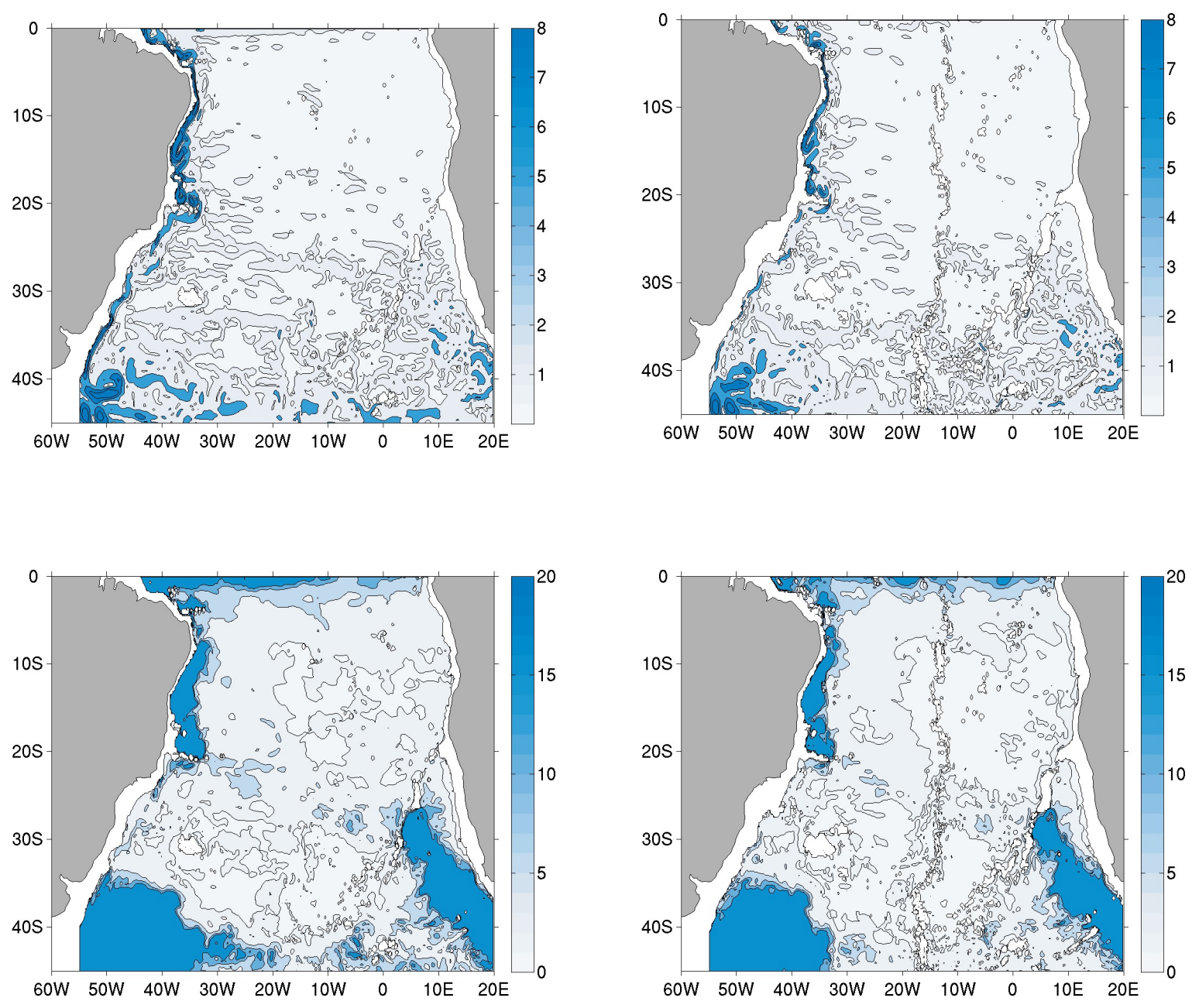
Figure 7
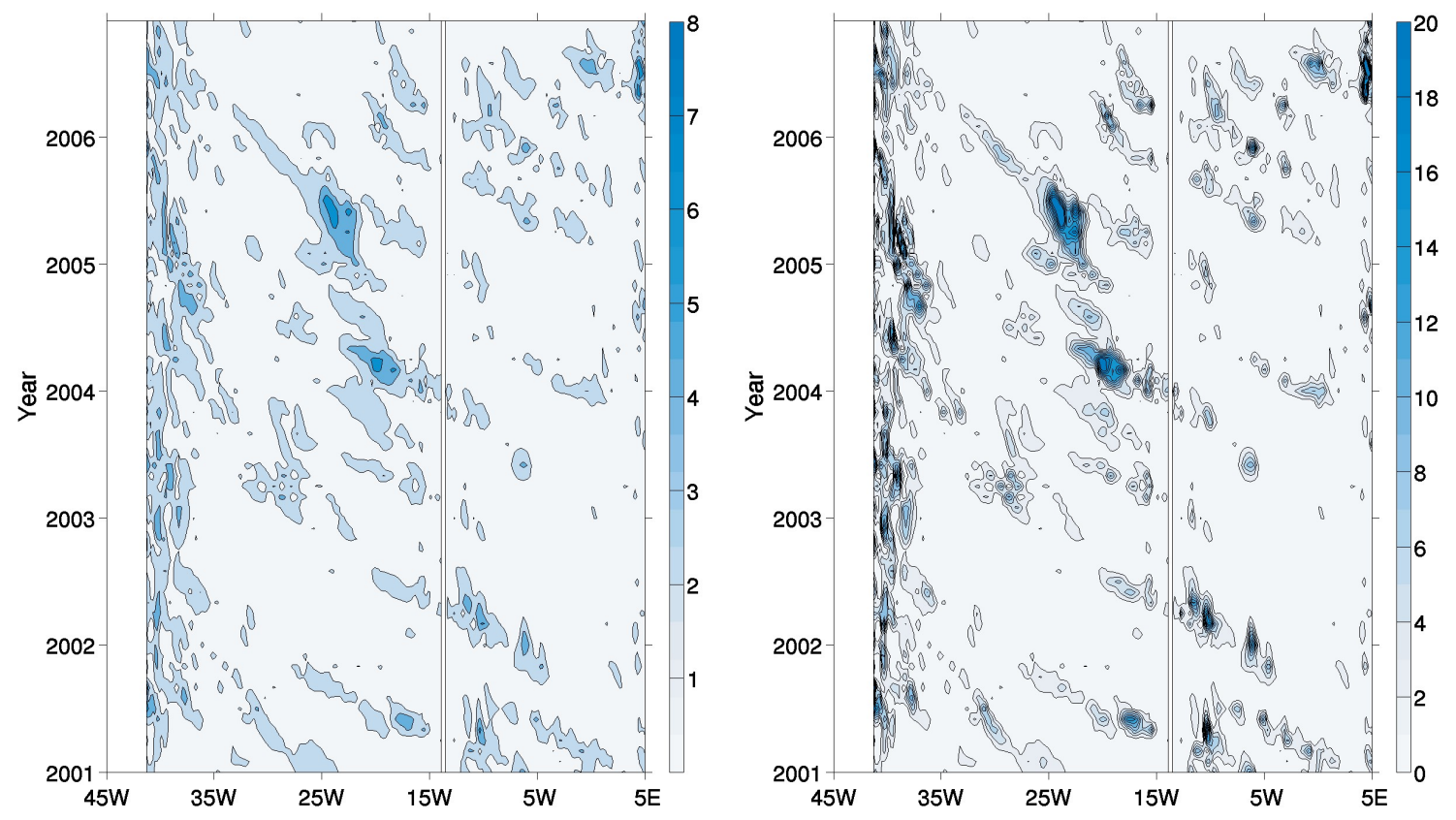
Figure 8

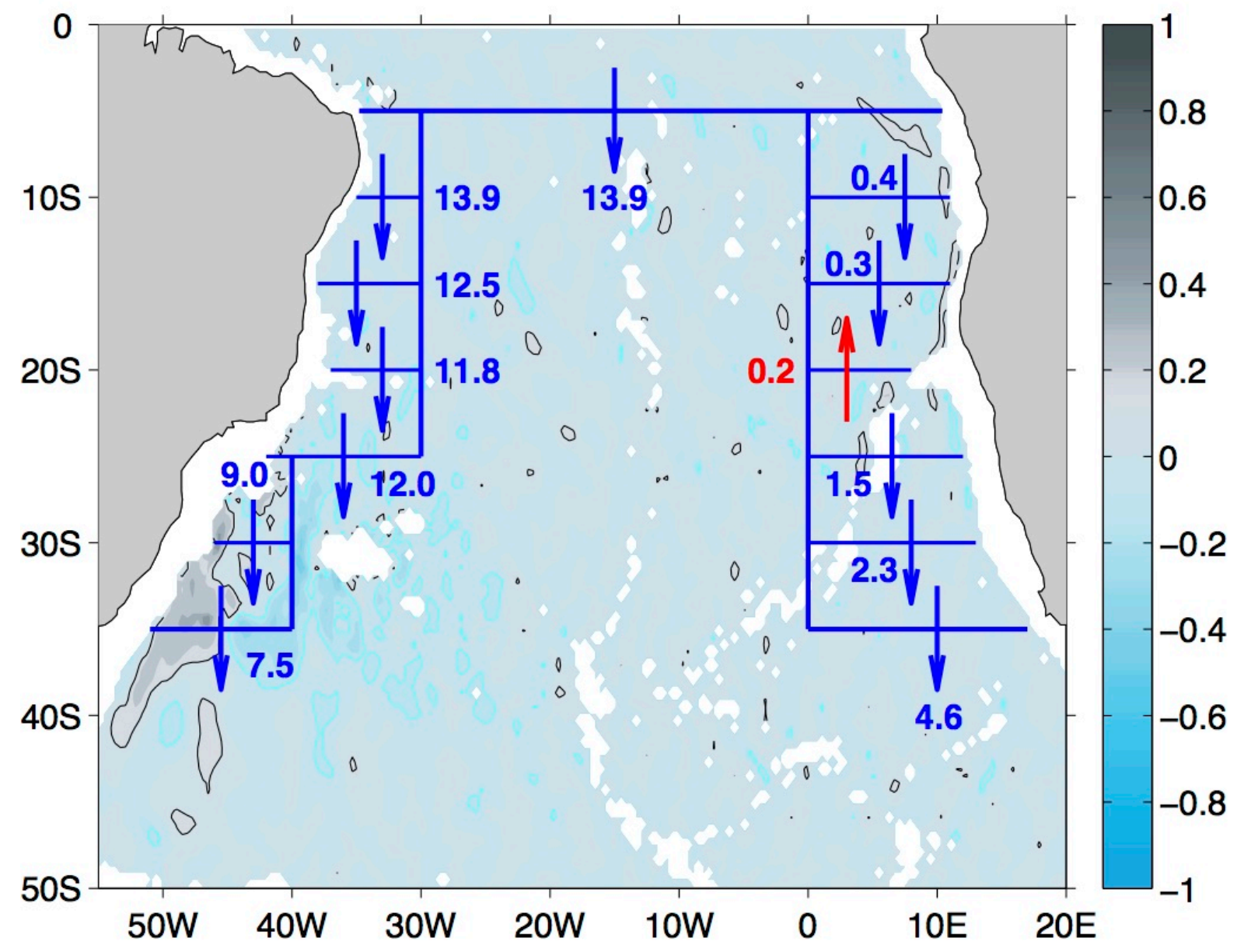




\section{Table I}

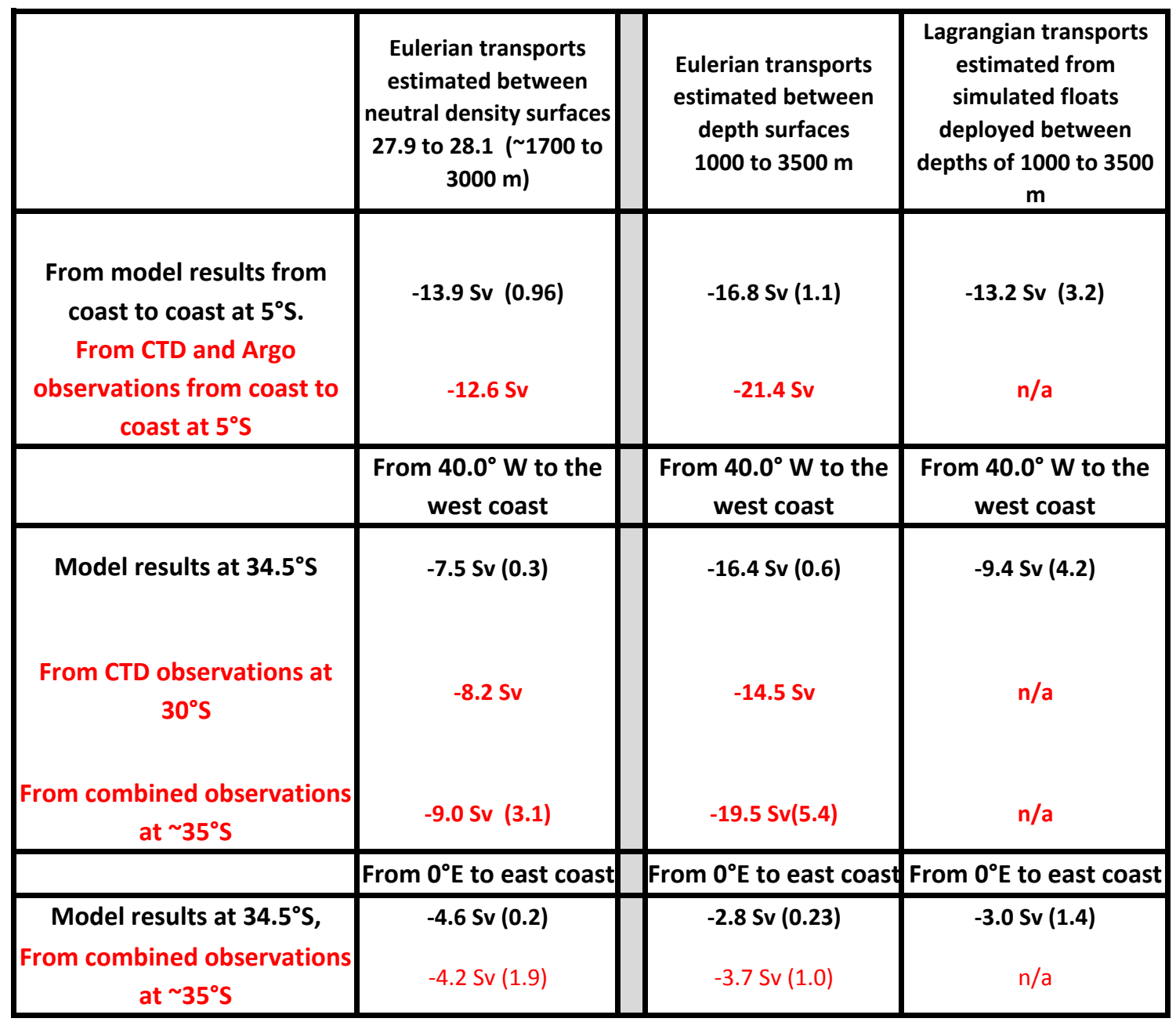

